\title{
Impact of ENSO longitudinal position on teleconnections to the NAO
}

Article

Accepted Version

Zhang, W., Wang, Z., Stuecker, M. F., Turner, A. G., Jin, F.-F. and Geng, X. (2019) Impact of ENSO longitudinal position on teleconnections to the NAO. Climate Dynamics, 52 (1-2). pp. 257-274. ISSN 0930-7575 doi: https://doi.org/10.1007/s00382018-4135-1 Available at https://centaur.reading.ac.uk/70071/

It is advisable to refer to the publisher's version if you intend to cite from the work. See Guidance on citing.

To link to this article DOI: http://dx.doi.org/10.1007/s00382-018-4135-1

Publisher: Springer

All outputs in CentAUR are protected by Intellectual Property Rights law, including copyright law. Copyright and IPR is retained by the creators or other copyright holders. Terms and conditions for use of this material are defined in the End User Agreement.

\section{www.reading.ac.uk/centaur}

\section{CentAUR}

Central Archive at the University of Reading

Reading's research outputs online 


\section{Impact of ENSO longitudinal position on teleconnections to

\author{
Wenjun Zhang ${ }^{1}$, Ziqi Wang ${ }^{1}$, Malte F. Stuecker ${ }^{2,3}$, Andrew G. Turner ${ }^{4,5}$, Fei-Fei \\ Jin $^{6}$, Xin Geng ${ }^{1}$ \\ ${ }^{1}$ CIC-FEMD/ILCEC, Key Laboratory of Meteorological Disaster of Ministry of Education, \\ Nanjing University of Information Science and Technology, Nanjing 210044, China \\ ${ }^{2}$ Department of Atmospheric Sciences, University of Washington, Seattle, Washington, USA. \\ ${ }^{3}$ Cooperative Programs for the Advancement of Earth System Sciences (CPAESS), University \\ Corporation for Atmospheric Research (UCAR), Boulder, Colorado, USA. \\ ${ }^{4}$ NCAS-Climate, University of Reading, Reading RG6 6BB, UK \\ ${ }^{5}$ Department of Meteorology, University of Reading, Reading RG6 6BB, UK \\ ${ }^{6}$ Department of Atmospheric Sciences, SOEST, University of Hawai'i at Manoa, Honolulu, HI \\ 96822, USA
}

Dec. 21, 2017

(Submitted to Climate Dynamics) 
While significant improvements have been made in understanding how the El Niño-Southern Oscillation (ENSO) impacts both North American and Asian climate, its relationship with the North Atlantic Oscillation (NAO) remains less clear. Observations indicate that ENSO exhibits a highly complex relationship with the NAO-associated atmospheric circulation. One critical contribution to this ambiguous ENSO/NAO relationship originates from ENSO's diversity in its spatial structure. In general, both eastern (EP) and central Pacific (CP) El Niño events tend to be accompanied by a negative NAO-like atmospheric response. However, for two different types of La Niña the NAO response is almost opposite. Thus, the NAO responses for the CP ENSO are mostly linear, while nonlinear NAO responses dominate for the EP ENSO. These contrasting extra-tropical atmospheric responses are mainly attributed to nonlinear air-sea interactions in the tropical eastern Pacific. The local atmospheric response to the CP ENSO sea surface temperature (SST) anomalies is highly linear since the air-sea action center is located within the Pacific warm pool, characterized by relatively high climatological SSTs. In contrast, the EP ENSO SST anomalies are located in an area of relatively low climatological SSTs in the eastern equatorial Pacific. Here only sufficiently high positive SST anomalies during EP El Niño events are able to overcome the SST threshold for deep convection, while hardly any anomalous convection is associated with EP La Niña SSTs that are below this threshold. This ENSO/NAO relationship has important implications for NAO seasonal prediction and places a higher requirement on models in reproducing 
the full diversity of ENSO. 


\section{Introduction}

The El Niño-Southern Oscillation (ENSO) is the predominant source of global inter-annual climate variability arising from coupled ocean-atmosphere interactions in the tropical Pacific (Bjerknes 1969; Wyrtki 1975; Schopf and Suarez 1988; Jin 1997; Neelin et al. 1998; Wallace et al. 1998). ENSO has received widespread attention due to its pronounced climate impacts around the globe (e.g., van Loon and Madden 1981; Ropelewski and Halpert 1987, 1996; Trenberth and Caron 2000). For instance, ENSO exhibits impacts on the North American climate via forced atmospheric Rossby waves known as the Pacific-North America (PNA) teleconnection pattern (Hoskins and Karoly 1981; Wallace and Gutzler 1981). Furthermore, ENSO affects East Asian climate through a modulation of the anomalous low-level anticyclone over the western North Pacific (WNP) (e.g., Zhang et al. 1996; Wang et al. 2000). The WNP anomalous anticyclone originates from the nonlinear interactions between ENSO and the warm pool annual cycle (Stuecker et al. 2015; Zhang et al. 2016) and is further amplified by local (Wang et al. 2000; Stuecker et al. 2015) and remote (Yang et al. 2007; Xie et al. 2009, 2016; Stuecker et al. 2015) air-sea coupled processes. In contrast, the linkages between ENSO and climate variability over the North Atlantic-European sector are much less clear.

Interannual variability of North Atlantic-European climate in winter is strongly affected by another prominent atmospheric circulation pattern - the North Atlantic Oscillation (NAO). This pattern represents a large-scale seesaw between the subtropical and polar atmospheric mass. Numerous efforts have been made to explore 
possible impacts of ENSO on NAO variability since the ENSO/NAO relationship can provide potential seasonal predictability for the climate in Europe (see an extensive review by Brönnimann 2007a). Early research argued that no ENSO-related climate impacts could be identified over the North Atlantic and adjacent Western Europe (e.g., Rogers 1984; Ropelewski and Halpert 1987; Halpert and Ropelewski 1992). This viewpoint was supported by subsequent studies, indicating that no significant ENSO/NAO connection can be detected (e.g., Trenberth and Caron 2000; Quadrelli et al. 2001; Wang 2002). However, this viewpoint was recently challenged by both observational analyses and various modeling experiments (e.g., Fraedrich and Muller 1992; Fraedrich 1994; Dong et al. 2000; Cassou and Terray 2001; Merkel and Latif 2002; Moron and Gouirand 2003; Gouirand et al. 2007; Brönnimann et al. 2007b; Ineson and Scaife 2009; Li and Lau 2012a). It is argued that despite large internal variability, a negative NAO-like atmospheric anomaly pattern usually coincides with canonical El Niño events, characterized by a colder and drier-than-normal climate over Western Europe during late winter. Correspondingly, La Niña events display approximately opposite impacts on the NAO.

The non-stationary behavior of the ENSO/NAO relationship is possibly associated with different modulating factors, such as natural variability in the extratropical circulation (Kumar and Hoerling 1998), tropical volcanic eruptions (Brönnimannet al. 2007b), other climate signals independent of ENSO (e.g., Mathieu et al. 2004; Garfinkel and Hartman 2010), and decadal changes of the background state (Wu and Zhang 2015). Moreover, the ambiguity of the ENSO/NAO relationship 
can be partly attributed to large inter-event variability of both ENSO and the NAO, partly due to short observational records, especially for earlier studies. It is worth mentioning that ENSO's impacts on the NAO are strongly seasonally modulated, with North Atlantic atmospheric anomalies that are approximately opposite in early winter (i.e., November-December) to those in late winter (i.e., January-March) (Moron and Gouirand 2003), which could also lead to discrepancies between different studies.

ENSO exhibits a considerable degree of diversity in its sea surface temperature (SST) anomaly pattern, which also affects its connection with the NAO. In recent decades, a new type of El Niño has been observed frequently in the central Pacific (CP hereafter), which differs considerably from the traditional El Niño that features a SST anomaly center over the Eastern Pacific (EP hereafter) (Larkin and Harrision 2005; Ashok et al. 2007; Weng et al. 2007; Kao and Yu 2009; Kug et al. 2009; Ren and Jin 2011). Many studies have reported the importance in their distinct regional climate impacts (e.g., Weng et al. 2007; Feng et al. 2010; 2016; Feng and Li 2011, 2013; Lee et al. 2010; Zhang et al. 2011, 2013, 2014; Xie et al. 2012; Yu et al. 2012). Similarly, La Niña events can also be separated into two types based on their SST anomaly patterns (Zhang et al. 2015). It is argued that these two ENSO types seem to have different impacts on the NAO (Graf and Zanchettin 2012; Zhang et al. 2015). However, this argument still needs further investigation based on more detailed observational and modeling analyses.

To date, the dynamical mechanisms addressing how tropical SST anomalies associated with ENSO influence the NAO variability have not been fully addressed. 
112

113

114

The atmosphere over the North Pacific is usually proposed to serve as the bridge linking the ENSO-associated diabatic heating in the tropical Pacific with atmospheric circulation anomalies over the North Atlantic (e.g., Wu and Hsieh 2004; Graf and Zanchettin 2012). The PNA-like teleconnection pattern over the North Pacific usually extends downstream to the North Atlantic and leads to a change in the quasi-stationary wave structures, which can be enhanced by eddy-mean flow interactions (e.g., Cassou and Terray 2001; Pozo-Vázquez et al. 2005; Graf and Zanchettin 2012). The stratosphere might also act as a mediator to connect the signal between the Pacific and Atlantic basins (e.g., Castanheira and Graf 2003; Ineson and Scaife 2009; Bell et al. 2009). As an additional pathway, several previous studies reported that ENSO could cause northern tropical Atlantic SST anomalies (e.g., Wolter 1987; Curtis and Hastenrath 1995; Alexander et al. 2002), which then further affect the North Atlantic atmospheric circulation (e.g., Watanabe and Kimoto 1999; Robertson et al. 2000). Finally, the ENSO-forced downstream development process of synoptic eddies provides a pathway to affect the NAO (e.g., Li and Lau 2012a,b; Drouard et al. 2015). In this argument, the low-frequency atmospheric circulation anomaly (ridge or trough) over the eastern Pacific and North America is emphasized, which modulates the meridional propagation of synoptic wave packets over the North Atlantic, which then favors occurrence of different NAO phases.

As discussed above, there appears little scientific consensus on the ENSO/NAO relationship and its associated physical mechanisms. For example, can a statistically significant relationship between ENSO and NAO variability be identified? If so, 
which dynamical mechanisms are responsible for this relationship? Our previous work provided an evidence for the existence of different types of La Niña based on their different impacts on the NAO (Zhang et al. 2015). The present study extends this analysis and investigates the linear and nonlinear relationships between ENSO and NAO and discusses the dominant mechanisms by using both observations and a suite of numerical model experiments. As we shall demonstrate, predominantly linear and nonlinear NAO responses are found associated with the CP and EP ENSO types, respectively. We will attribute this difference mainly to the varying atmospheric responses to the eastern tropical Pacific SST anomalies.

In the reminder of this paper, section 2 introduces the data, methodology, definition of ENSO events, and our experimental design. Section 3 illustrates uncertainties of the ENSO/NAO relationship. The different linkages between the NAO and the two distinct ENSO types are examined in section 4. Further evidence of this complex ENSO/NAO relationship is shown in section 5. Possible dynamical mechanisms for the different ENSO/NAO relationships are discussed in section 6 . The major conclusions are summarized and discussed in section 7.

\section{Data, Methodology, definition of ENSO events, and Experimental}

\section{design}

\subsection{Data and Methodology}

Monthly SST anomalies associated with ENSO were examined based on the Hadley Centre sea ice and SST data set (HadISST) version 1.1 (Rayner et al. 2003). 
The atmospheric circulation was investigated using National Center for Environmental Prediction (NCEP)/National Center for Atmospheric Research (NCAR) reanalysis-1 data (Kalnay et al. 1996). Precipitation data are taken from the Global Precipitation Climatology Centre (GPCC) (Rudolf et al. 2005). We also utilized the global monthly land surface temperature analysis collected from the Global Historical Climatology Network version 2 and the Climate Anomaly Monitoring System (GHCN_CAMS) (Fan and van den Dool 2008). To describe the NAO-associated atmospheric activity, the NAO index is defined as the difference in normalized sea-level pressure (SLP) zonally-averaged from $80^{\circ} \mathrm{W}$ to $30^{\circ} \mathrm{E}$ between $35^{\circ} \mathrm{N}$ and $65^{\circ} \mathrm{N}$ (Li and Wang 2003). Other NAO indices, such as the index defined by Hurrell (Hurrell 1995) and Climate Prediction Center (CPC; http://www.cpc.ncep.noaa.gov/products/precip/CWlink/pna/nao.shtml) were also examined and the conclusions remain the same.

Our analyses in this paper cover the period 1948-2014 and anomalies for all variables were computed as the deviations from a 30-year climatological mean (1981-2010). A 6-120 month band-pass filter was applied to each dataset using the second-order Butterworth filter designed by Parks and Burrus (1987), to focus on ENSO-related interannual variability. The first and last three years of the datasets were removed in the following analyses to avoid possible boundary distortion associated with the band-pass filtering. Linear correlation and composition analyses were used to investigate the ENSO/NAO relationship. Statistical significance was determined using the two-tailed Student's t-test. 


\subsection{Definition of ENSO events}

ENSO events usually reach their peak phase during boreal winter (December-January-February, DJF). However, the largest impact of ENSO on the NAO can usually be found during late winter (January-February-March, JFM) (e.g., Zhang et al. 2015). Thus, we use the DJF Niño3.4 index (SST anomalies averaged over $5^{\circ} \mathrm{S}-5^{\circ} \mathrm{N}$ and $120^{\circ}-170^{\circ} \mathrm{W}$ ) as a measure of ENSO and the NAO index calculated in JFM to characterize the NAO. The CPC definition is utilized to identify ENSO winters based on a threshold of $\pm 0.5^{\circ} \mathrm{C}$ of the Niño3.4 SST anomalies for five consecutive overlapping seasons. Many regional ENSO indices are able to separate El Niño events into two types (i.e., Ashok et al. 2007; Kao and Yu 2009; Ren and Jin 2011), however they fail to effectively distinguish different La Niña types (Zhang et al. 2015), especially during the period before the 1980s (Ren et al. 2013). Here we identify different ENSO types by the spatial distribution of SST anomalies, same as our previous definition (Zhang et al. 2011, 2013, 2014, 2015), which can effectively distinguish two types for both El Niño and La Niña events. The events are classified into EP (CP) ENSO winters if the largest SST anomaly center occurs east (west) of $150^{\circ} \mathrm{W}$ during the developing and mature (September to February) ENSO phases. Among them, two El Niño events $(1987 / 88,2006 / 07)$ and three La Niña events (1970/71, 1999/00, 2007/08) are defined as a mixed type (or basin-wide mode) since the SST anomalies cover both EP and CP regions. Here, ENSO years are labeled Year(0)/Year(1), where 0 and 1 refer to the ENSO developing and decaying year, respectively. Some ENSO events coincide with tropical volcanic eruptions, which 
strongly affect the atmospheric circulation over the North Atlantic and Europe for about 1-2 years after the eruption (e.g., Robock 2000; Driscoll et al. 2012). Hence, ENSO events (i.e., 1982/83 and 1991/92) following major tropical volcanic eruptions are excluded in our analysis. Especially for the 1991 Pinatubo eruption, the second largest eruption in the $20^{\text {th }}$ century, its climate impacts over Europe can be detected after several years following the eruption (e.g., Xiao and Li 2011). To exclude these volcanic eruption signals, the following two and four years were removed after the 1982 and 1991 eruptions, respectively. The two types of ENSO winters analyzed in this paper are listed in Table 1. Each category features 8 samples, other than the CP El Niño group, which contains 9 events.

\subsection{Experimental design}

To examine the possible impacts of ENSO SST anomalies on the NAO, modeling experiments were conducted using the Geophysical Fluid Dynamics Laboratory (GFDL) global Atmospheric Model version 2.1 (AM2.1) (The GFDL Global Atmospheric Model Development Team, 2004) with a horizontal resolution of $2.5^{\circ}$ longitude $\times 2^{\circ}$ latitude. As a reference state, climatological (seasonally varying) SSTs were used to force the atmospheric model. Additionally, a suite of sensitivity experiments (EPW, CPW, EPC, and CPC) was designed (Table 2). For the first simulation (EPW), the SST anomalies for composites of the EP El Niño events listed in Table 1 were imposed on the monthly climatological SST from October to February in the tropical Pacific $\left(30^{\circ} \mathrm{S}-30^{\circ} \mathrm{N}, 120^{\circ} \mathrm{E}-90^{\circ} \mathrm{W}\right)$ (Table 2). Anomalies outside of the 
region were set to zero to limit our analysis to the effects of tropical Pacific SST anomalies. We note that the SST anomalies outside of the tropical Pacific also play some role in ENSO-induced climate impacts, which are not considered in this paper. The other three experiments (CPW, EPC, and CPC in Table 2) are the same as the EPW experiment, except that the SST anomalies are the composites for other different ENSO types (the CP El Niño, EP La Niña, and CP La Niña events in Table 1). Each simulation is integrated for 15 years and the last 10 years of the integrations were used to avoid influences of the initial conditions. A composite of these 10 years removes most of the internal variability.

\section{Uncertainties of the ENSO/NAO relationship}

First, we investigate the time series of the DJF Niño3.4 and JFM NAO indices (Fig. 1a). These two indices display conspicuous interannual variability that is only weakly anti-correlated $(\mathrm{R}=-0.23$, insignificant at the $95 \%$ confidence level). Also, no robust linear relationship can be established when considering sliding correlations with 11- and 21-year windows respectively (Fig. 1b). To address possible influences of volcanic eruption events on the ENSO/NAO relationship, we further calculate the correlation coefficient between the Niño3.4 and NAO indices after removing the previously defined eruption years from both time series. After removing this influence, we detect a weak but statistically significant (at the 95\% confidence level) relationship ( $\mathrm{R}=-0.33$ in Table 3), suggesting that in general El Niño events (as measured by DJF Niño3.4) tend to be accompanied by a negative NAO phase, and La 
Niña events by a positive NAO.

Next, we show a scatterplot of Niño3.4 and NAO indices during the ENSO winters (Fig. 2). Most (14 of 17) El Niño events are accompanied by a negative NAO phase, consistent with many previous studies (e.g., Brönnimann 2007a; Li and Lau 2012a). Only three El Niño events (i.e., 1953/54, 1972/73, 2002/03) coincide with a weak positive NAO phase. However, no simple relationship is detected between the Niño3.4 and NAO indices for La Niña events. Around half of the La Niña winters exhibit a positive NAO phase, while the other half are accompanied by a negative NAO phase. We hypothesize that this unstable La Niña/NAO relationship could explain the weak correlation between the Niño3.4 and NAO indices. To better understand the different NAO response to La Niña, we show the composite SST anomaly patterns during La Niña/NAO+ (Fig. 3a) and La Niña/NAO- (Fig. 3b) winters. La Niña winters corresponding to a positive NAO phase exhibit a negative SST anomaly center, strongest over the central equatorial Pacific west of $150^{\circ} \mathrm{W}$ with relatively weak anomalies in the eastern equatorial Pacific, which is the characteristic pattern of the CP La Niña (Zhang et al. 2015). In contrast, the SST anomalies associated with La Niña/NAO- events have maximum negative SST anomalies in the equatorial eastern Pacific east of $150^{\circ} \mathrm{W}$, which resembles the SST anomaly pattern of the EP La Niña. This suggests that the NAO responses are very sensitive to the zonal location of La Niña-related SST anomalies, which have been described in our previous study (Zhang et al. 2015). This separation of La Niña events with regard to NAO phase is also evident in Figure 2. This suggests that ENSO has indeed a close 
connection with the NAO, which was not easily detected in earlier studies due to the nonlinear La Niña/NAO relationship.

\section{Inconsistent linkages between the NAO and two types of ENSO}

Next, we investigate ENSO event composites to further examine the relationship between the NAO and the two types of ENSO. First, we show the SST anomaly patterns to demonstrate the validity of two-type ENSO classification (Fig. 4). It can be seen that the SST anomaly patterns related to the different ENSO types are well separated. They are characterized by a different zonal location of the SST anomalies and the corresponding near-surface wind anomalies (SST maxima at approximately $165^{\circ} \mathrm{W}$ and $115^{\circ} \mathrm{W}$ for $\mathrm{CP}$ and EP ENSO respectively). Note that the SST anomaly patterns associated with the two La Niña types are almost the same as those shown in Figure 3 associated with different phases of the NAO. Furthermore, it can be seen that the SST amplitude is larger for EP El Niño than for CP El Niño. In contrast, the SST amplitude for EP La Niña is smaller than for CP La Niña.

To examine the extra-tropical response, Northern Hemisphere composite SLP anomalies for the different ENSO types are shown in Figure 5. We observe an atmospheric Rossby wave response to diabatic heating caused by positive SST anomalies in the tropical Pacific. Positive PNA-like atmospheric circulation patterns are seen during both EP and CP El Niño winters, albeit with different spatial extent and amplitude (Fig. 5a, b). Compared to the EP El Niño composite, we observe negative SLP anomalies over the North Pacific for CP El Niño that are shifted 
southeastward and have a larger extent. Importantly, both EP and CP El Niño winters exhibit extra-tropical atmospheric responses of the same sign over the Atlantic. In comparison, the negative NAO-like SLP response (characterized by weakened subtropical high and polar low) is larger for CP than EP El Niño events, despite the larger SST amplitude during EP El Niño events. Unlike the CP El Niño events, the EP El Niño-associated SLP anomalies over the North Atlantic are relatively weak and are significant only above the $80 \%$ confidence level, thus exhibiting a certain degree of uncertainty. This uncertainty could be due to the large diversity in the amplitude of EP El Niño events (Toniazzo and Scaife 2006). Differences in teleconnection patterns associated with the two El Niño types can also be observed in the Southern Hemisphere (Lim et al., 2013; Wilson et al., 2014, 2016). In the Northern Hemisphere, both La Niña types are characterized by negative PNA-like atmospheric circulation anomalies that appear as a response to the negative SST anomalies in the tropical Pacific (Fig. 5c,d). Correspondingly, positive SLP anomalies are evident for both types over the North Pacific, indicating a weakened Aleutian low. In contrast, the CP La Niña-associated SLP anomalies are displaced southeastward compared to the EP La Niña, which is similar to the Pacific signal seen for the two El Niño types. Despite these similar anomalies over the North Pacific, an almost opposite atmospheric anomaly is observed over the North Atlantic and Western Europe for the two La Niña types. The EP La Niña events exhibit a negative NAO-like atmospheric response (weakened subtropical high and polar low) with its center located over the eastern North Atlantic and Western Europe (Fig. 5c). In contrast, the CP La Niña events are 
accompanied by a positive NAO-like atmospheric anomaly pattern (strengthened

311 subtropical high and polar low) with its center located over the western-to-central

312 North Atlantic (Fig. 5d). These NAO-like responses to different ENSO types can in

313 fact be seen for almost the entire troposphere over the North Atlantic (Fig. 6),

314 exhibiting a quasi-barotropic structure. Notably, the North Atlantic response seems

315 weak for mid-latitude negative anomalies during EP El Niño events (Fig.6a).

316 The subtropical jet is usually argued to serve as a mediator linking ENSO and the

317 North Atlantic atmosphere (e.g., Graf and Zanchettin 2012). Figure 7 shows the 318 composite $300 \mathrm{hPa}$ zonal wind anomalies during different types of ENSO winters. For

319 both types of El Niño events, the zonal wind anomalies exhibit a tripolar structure and

320 tilt slightly northeastward (Fig. 7a,b). These anomalies extend zonally from the North

321 Pacific toward the North Atlantic. Similar to Figure 5a, the EP El Niño-associated

322 anomalies are relatively weak over the North Atlantic and statistically significant only

323 above the $80 \%$ confidence level. In contrast, the CP El Niño-associated anomalies

324 exhibit a larger zonal extent and amplitude than those for EP El Niño. Overall, the

325 Atlantic subtropical westerly jet tends to be weakened for both El Niño types,

326 corresponding to the negative NAO-like atmospheric responses. A very similar

327 meridional structure of $300 \mathrm{hPa}$ zonal wind anomalies is observed for the two La Niña

328 types over the North Pacific, but with farther northward displacement by about $10^{\circ}$ for

329 EP La Niña compared to CP La Niña (Fig. 7c,d). The CP La Niña-related zonal wind

330 anomalies extend to the North Atlantic and Western Europe region, where

331 anomalously weak upper-level winds are found as far east as the Mediterranean. In 
contrast, the EP La Niña-associated zonal wind anomalies are more zonally constrained (more like a wave train structure) and of almost opposite structure over the North Atlantic. Consistent with the NAO response, a weakened and strengthened Atlantic jet concurs with EP and CP La Niña events, respectively (Fig. 7c,d). Interestingly, the $300 \mathrm{hPa}$ wind response to $\mathrm{CP}$ ENSO is quite linear, with roughly equal and opposite patterns in response to CP El Niño and CP La Niña (Fig. 7b,d). This is not the case for EP ENSO where the response is distinctly nonlinear. Corresponding to the different Atlantic jet anomalies, the activity of the synoptic eddies (2-10-day timescale) is weakened over the North Atlantic for the two El Niño types and EP La Niña events, while it is strengthened for CP La Niña events (not while it is nonlinear for EP ENSO. even Eurasia are closely associated with NAO phase (for a review, refer to Jones et al. 2003). Motivated by our previous analyses we hypothesize that different ENSO types may give rise to distinct climate anomalies over Eurasia. As shown in Section 4, the 
negative NAO-like responses to the two El Niño types and EP La Niña events are accompanied by a weakened Atlantic jet (Fig. 7a-c), which limits the transport of warm and moist air from the North Atlantic to the northern Eurasian land areas. Simultaneously, the strengthened zonal winds south of the Atlantic jet core (Fig. 7a-c) lead to enhanced warm and moist air transported into southern Eurasia. As expected, northern Eurasia (roughly north of $40^{\circ} \mathrm{N}$ ) experiences a colder than normal winter during the two types of El Niño and EP La Niña (Fig. 8a-c). At the same time, the southern part of Eurasia tends to experience warmer than normal winters. In contrast, CP La Niña events tend to result in positive NAO-like atmospheric anomalies and a strengthened Atlantic jet. Therefore, warmer and wetter air can be transported into northern Eurasia, which results in positive surface temperature anomalies in Europe during CP La Niña winters (Fig. 8d). Precipitation anomaly differences are approximately co-located with the surface temperature anomalies, characterized by reduced precipitation for the two El Niño types and EP La Niña and enhanced precipitation for CP La Niña over northern Eurasia (not shown), albeit with much larger spatial non-uniformity. Although EP and CP El Niño events have similar impacts on the Eurasian climate, a remarkable difference is evident in the spatial extent and amplitude of the climate anomalies (Fig. 5 and 8).

\subsection{Experiments of ENSO forcing on European climate variability}

We utilize a series of general circulation model experiments to verify the identified NAO impacts of tropical SST anomalies associated with different ENSO 
types (as listed in Table 2 and described in Section 2.3). Figure 9 shows the anomalous sea-level pressure (SLP) responses to the different prescribed ENSO

378 forcings. Simulated EP and CP El Niño winters are both characterized by a 379 strengthened Aleutian Low and negative NAO phase (Fig. 9a,b), which is roughly 380 consistent with the observations. Both EP and CP La Niña forcings generate a 381 weakened Aleutian Low. However, they simulate almost opposite atmospheric 382 responses over the North Atlantic (Fig. 9c,d), which can also be seen in experiments conducted with the NCAR Community Atmospheric Model version 5 (CAM5; Zhang et al. 2015). Consistent with observations, opposite NAO responses are found when the EP and CP La Niña-related SST anomalies are imposed. It is notable that the

386 simulated atmospheric responses over Western Europe are weaker than what we see in the observations (Figure 5c and 9c). experiments. Also consistent with the observations, the simulated zonal wind 
North Atlantic for the EP La Niña compared to CP La Niña events. The fact that these features are simulated in our idealized experiments suggests that the different NAO responses to EP and CP ENSO may be robust. We note that some obvious differences exist in the EP El Niño composites between the observations and the model simulation, but importantly they both consistently capture the positive PNA phase and negative NAO phase. These differences could be partly explained by the large inter-event variability in amplitude of EP El Niño events. In particular, the super El Niño events (e.g., 1972/73 and 1997/98) display pronounced differences in local air-sea coupled features and in the SST anomalies outside of the tropical Pacific region, which are not considered in our experimental design.

\section{Possible mechanisms for the unstable ENSO/NAO relationship}

Our analyses so far demonstrated that different ENSO types exhibit complex linkages with the NAO phase. CP ENSO (i.e., CP El Niño and CP La Niña) displays linear impacts on the NAO. In contrast, EP ENSO (i.e., EP El Niño and EP La Niña) shows nonlinear impacts on the NAO. To explore possible reasons for these differences, we decompose analysis into linear and nonlinear SST and atmospheric anomalies associated with the two ENSO types (Fig. 11). The degree of nonlinearity is determined by adding composites from two opposing phases of ENSO. Should the result be zero (i.e., the patterns associated with a particular field are exactly equal and opposite for El Niño and La Niña phases), then the ENSO response is perfectly linear. Precipitation associated with tropical deep convection is a good indicator of the 
linearity of the impacts of tropical SST anomalies, with the caveat that precipitation observations over the ocean are only available after the late 1970s. Thus, we use SLP anomalies to explore the local atmospheric response over the tropical Pacific instead of precipitation. Positive SST and negative SLP anomalies are evident in the eastern tropical Pacific, while negative SST and positive SLP anomalies exist in the western tropical Pacific for the linear part of EP ENSO (Fig. 11a), thus displaying typical EP ENSO features. In contrast, the linear SST anomalies for the CP ENSO are shifted westward to the central and western tropical Pacific (Fig. 11b). Correspondingly, the linear part of negative SLP anomalies exhibits the same westward shift for CP ENSO events. Importantly, CP ENSO does not exhibit a significant nonlinear component over the equatorial Pacific (Fig. 11d is mostly near-zero). This implies that negative and positive CP ENSO events will also not excite nonlinear teleconnection anomalies over the extra-tropics. Although almost no nonlinear SST anomaly appears over the tropical Pacific for the EP ENSO, we observe a strong nonlinear SLP anomaly response to the EP ENSO (Fig. 11c), whose amplitude is comparable to the linear component (compared to Fig. 11a).

Next, we examine the experimental results to verify the different relationships between SST forcing and atmospheric responses for these two ENSO types. For the linear part, the observed SLP features are well captured by the experiments forced with EP ENSO-related SSTs in the tropical Pacific. For example, positive and negative SLP anomalies emerge over the western and eastern tropical Pacific, respectively (Fig. 12a). Similarly, the tropical Pacific SST forcing associated with CP 
442 ENSO can reproduce the westward extension of the SLP response compared to EP 443 ENSO (Fig. 12b). In comparison, relatively large negative SLP anomalies are seen in 444 the eastern tropical Pacific for the EP nonlinear component (Fig. 12c), which cannot 445 be seen for the CP case (Fig. 12d). Consistent with the observations, the atmospheric responses to the two types of ENSO are very different over the eastern tropical Pacific, despite a systematic bias in the northern and western tropical Pacific for both EP and 448 CP ENSO events. These biases are possibly attributed to a combination of the 449 idealized experimental design (SST anomalies are set to zero outside of the tropical 450 Pacific), a one-way forcing from the ocean to atmosphere without considering 451 coupled ocean-atmosphere feedbacks, and model mean state biases. anomalies), thus convection and associated SLP anomalies usually exhibit a nonlinear relationship with SST anomalies. As the CP region is located near the eastern edge of the tropical Pacific warm pool with relatively high climatological SSTs, anomalous Fig. 13 to confirm the greater nonlinear atmospheric responses to ENSO in the eastern tropical Pacific. The composite difference between positive and negative phases of 
ENSO (the linear response) shows positive precipitation anomalies in the eastern equatorial Pacific $\left(155^{\circ}-90^{\circ} \mathrm{W}, 5^{\circ} \mathrm{S}-5^{\circ} \mathrm{N}\right)$ for both EP and CP ENSO (the latter of approximately half amplitude compared to EP ENSO). For the simulated nonlinear component, positive precipitation anomalies are evident in the eastern Pacific for the EP ENSO forcing (indicating a high degree of nonlinearity), with amplitude comparable to the CP linear component. In contrast, almost no nonlinear precipitation anomalies are seen for the CP ENSO forcing. The degree of nonlinearity could also be diagnosed as the ratio of the magnitudes of nonlinear to linear components.

Hence, the nonlinear relationship between SST and atmospheric response can be well reproduced by the model experiments. We emphasize that these nonlinear convection anomaly responses result in very different teleconnection patterns over the extra-tropics. Therefore, this nonlinearity is likely an important factor for determining the distinct NAO responses to different ENSO types in the observation.

\section{Conclusions and Discussion}

We use reanalysis data in conjunction with ENSO and NAO indices of the 1948-2014 period to determine impacts of different ENSO types (central and east Pacific events, CP and EP) on North Atlantic climate variability. A stable relationship is found between ENSO and atmospheric anomalies in the North Pacific region. However, no consistent linear relationship is found between ENSO and the NAO. We found that the complex ENSO/NAO relationship is mainly modulated by the different ENSO flavors once the impacts of volcanic activity are removed. Both 
types of El Niño (EP and CP) are accompanied by a negative NAO phase over the

487 North Atlantic, albeit with different intensities. In contrast, almost opposite atmospheric anomaly structures are detected over the North Atlantic for the two types of La Niña. A positive NAO phase is associated with CP La Niña winters, while a negative NAO phase is associated with the EP La Niña winters. Moreover, these results based on the reanalysis data are evidenced by the observed land surface

492 temperature over the Eurasian region and reproduced by the experiments driven by 493 imposed tropical Pacific SST anomalies associated with ENSO. We note that the composite NAO-associated atmospheric anomalies for EP ENSO events, especially for EP El Niño, are weaker than those to CP ENSO events. This difference may be 496 due to different zonal locations of the ENSO-related air-sea action center. Compared to CP ENSO events, the EP ENSO-associated SST anomalies are located in the eastern tropical Pacific where the climatological SSTs are colder. These different background states likely explain why the atmospheric responses to the same SST

500 anomaly amplitude are weaker. In addition, the large diversity among amplitude of 501 EP El Niño events increases the uncertainty in their climate impacts.

While CP ENSO events display linear impacts on the North Atlantic 503 atmospheric circulation, EP ENSO events exhibit nonlinear impacts. These varying extra-tropical atmospheric responses to two different ENSO types are mainly related to local nonlinear air-sea coupling in the tropical Pacific. Although the SST anomalies for our ENSO type composites are quasi-linear, we observe very different 507 local atmospheric responses due to the nonlinear SST threshold for deep convection. 
Thus, our conclusion is that nonlinear local atmospheric responses can further lead to different extra-tropical atmospheric anomalies (such as the NAO) since they will excite different wave propagation patterns through the troposphere.

Although ENSO originates in the tropical Pacific, its impacts can be detected in remote oceans through the so-called atmospheric bridge mechanism (e.g., Klein et al. 1999; Alexander et al. 2002). Some studies reported that ENSO-associated tropical Atlantic SST anomalies could serve as a mediator to connect the tropical Pacific SST anomalies with the NAO (e.g., Watanabe and Kimoto 1999; Robertson et al. 2000). As seen previously (Fig. 4a,b), pronounced positive SST anomalies are evident in the northwestern tropical Atlantic during EP Niño events, which are absent during CP El Niño events. In contrast, negative SST anomalies occur in the northern tropical Atlantic for both EP and CP La Niña events (Fig. 4c,d). Our experiments show that only tropical Pacific SST anomaly forcings associated with different ENSO types can well reproduce the observed NAO responses, suggesting that tropical Atlantic SST anomalies are not a key factor for the NAO responses to ENSO. Moreover, our previous experiments suggested that these tropical Atlantic SST anomalies during ENSO events could play a minor role for the NAO (Zhang et al. 2015). To further investigate possible effects of tropical Atlantic SST anomalies on the extra-tropical atmospheric circulation, we show in Fig. 14 the partial correlation coefficient of the observed SLP anomalies with SST anomalies in the tropical North Atlantic $\left(0^{\circ}-30^{\circ} \mathrm{N}\right.$, $20^{\circ}-80^{\circ} \mathrm{W}$ ), after the ENSO influence was linearly removed. Pronounced positive and negative SLP anomalies emerge over the north and south of the North Atlantic 
respectively, a pattern that resembles a negative NAO phase. However, no significant Aleutian Low anomalies can be found over the Pacific basin. This indicates that SST anomalies in the tropical North Atlantic could have some contribution to the NAO although they are not able to induce large-scale extra-tropical atmospheric circulation anomalies in the same way as ENSO. However, SST anomalies in the tropical North

Atlantic seem unable to explain diverging NAO responses to different ENSO types.

anomalies associated with different ENSO types result in varying NAO responses. To explore possible effects of stratospheric processes, we inspected the signal of the zonal wind anomalies at $60^{\circ} \mathrm{N}$ (Fig. 15) and found no significant signal propagation from the stratosphere to troposphere. This result is supported by our model experiments (not shown). However, we cannot fully exclude the possibility that the stratosphere plays a role in the ENSO/NAO connection due to sparse input observations to the reanalysis assimilation scheme, and poor performance of the model at upper levels. For example, a recent study argued that ENSO have impacts on climate over Northern Atlantic and Eurasia mainly through the stratospheric pathway (Butler et al. 2014).

Another possible cause of the divergent NAO responses to different ENSO types could be the downstream development of synoptic eddies. The low-frequency atmospheric anomalies over the northeast Pacific are very important for the propagation of the Pacific jet (Drouard et al. 2015). For example, the ridge anomaly over the northeastern Pacific can deflect the Pacific jet while the trough anomaly in 
this location can maintain the Pacific jet extending in a zonal orientation. Therefore, during both types of El Niño events the trough anomaly over the northeastern Pacific favors a zonally oriented propagation of the Pacific jet. In contrast, the zonal location of the Northern Pacific SLP anomalies for both La Niña types differs significantly (Figure 5c,d). During CP La Niña, high SLP anomalies are shifted southward (compared to EP La Niña) and the northeastern Pacific is characterized by weak negative SLP anomalies. Thus, the Pacific jet extends zonally from the Pacific to the North Atlantic. For the EP La Niña, high SLP anomalies are located over the northeast Pacific, which act to deflect the Pacific jet. According to the study by Drouard et al. (2015), the different propagation orientation of the Pacific jet could result in varying downstream eddy structures and thus cause opposite NAO phases.

This paper adds to the body of work stating the importance of taking ENSO diversity into account when considering its impacts on remote climate variability. Coupled dynamical seasonal prediction models in use at various meteorological agencies must therefore be able to simulate the range of ENSO diversity in terms of its longitudinal location in order to correctly capture any additional skill offered to the NAO.

Acknowledgements: This work was supported by the SOA Program on Global Change and Air-Sea interactions (GASI-IPOVAI-03), the National Nature Science Foundation of China (41675073), and Jiangsu 333 High-level Talent Cultivation Project and the Six Talent Peaks. MFS was supported by the NOAA Climate and 
574 Global Change Postdoctoral Fellowship Program, administered by UCAR's 575 Cooperative Programs for the Advancement of Earth System Sciences (CPAESS).

576 AGT was supported by the NCAS-Climate Core Agreement, contract number $577 \quad \mathrm{R} 8 / \mathrm{H} 12 / 83 / 00$.

578 


\section{Reference}

580

581

582

583

584

585

586

587

588

589

590

591

592

593

594

595

596

597

598

599

600

601

602

603

604

605

606

607

Ashok K, Behera SK, Rao SA, Weng HY, Yamagata T (2007) El Niño Modoki and its possible teleconnection. J Geophys Res 112:C11007. doi:10.1029/2006JC003798

Alexander MA, Bladé I, Newman M, Lanzante JR, Lau NC, Scott JD (2002) The atmospheric bridge: The influence of ENSO teleconnections on air-sea interaction over the global oceans. J Clim 15:2205-2231

Bell CJ, Gray LJ, Charlton-Perez AJ, Joshi MM (2009) Stratospheric communication of El Niño teleconnections to European winter. J Clim 22:4083-4096

Bjerknes J (1969) Atmospheric teleconnections from the equatorial Pacific. Mon Wea Rev 97:163-172

Brönnimann S (2007a) Impact of El Niño-Southern Oscillation on European climate. Rev. Geophys 45:RG3003. doi:10.1029/2006RG000199

Brönnimann S, Xoplaki E, Casty C, Pauling A, Luterbacher J (2007b) ENSO influence on Europe during the last centuries. Clim Dyn 28:181-197

Butler AH, Polvani LM, Deser C (2014) Separating the stratospheric and tropospheric pathways of El Niño-Southern Oscillation teleconnections. Environ Res Lett 9: 024014. doi:10.1088/1748-9326/9/2/024014

Cassou C, Terray L (2001) Oceanic forcing of the wintertime low-frequency atmospheric variability in the North Atlantic European sector: A study with the ARPEGE model. J Clim 14: 4266-4291

Castanheira JM, Graf HF (2003) North Pacific-North Atlantic relationships under stratospheric control? J Geophys Res 108:4036. doi:10.1029/2002JD002754

Curtis S, Hastenrath S (1995) Forcing of anomalous sea-surface temperature evolution in the tropical Atlantic during Pacific warm events. J Geophys Res 100C: $15835-15847$.

Dong BW, Sutto RT, Jewson SP, O’Neill A, Slingo JM (2000) Predictable winter climate in the North Atlantic sector during the 1997-1999 ENSO cycle. Geophys Res Lett 27:985-988

Driscoll S, Bozzo A, Gray LG, Robock A, Stenchikov G (2012) Coupled Model 
Intercomparison Project 5 (CMIP5) simulations of climate following volcanic eruptions. J Geophys Res 117:127-135

Drouard M, Riviere G, Arbogast P (2015) The link between the North Pacific climate variability and the North Atlantic Oscillation via downstream propagation of synoptic waves. J Clim 28:3957-3976

Fan Y, van den Dool H (2008) A global monthly land surface air temperature analysis for 1948-present. J Geophys Res 113:D01103. doi:10.1029/2007JD008470

Feng J, Li JP (2011) Influence of El Niño Modoki on spring rainfall over South China. J Geophys Res 116:D13102. doi:10.1029/2010JD015160

Feng J, Li JP (2013) Contrasting impacts of two types of ENSO on the boreal spring Hadley circulation. J Clim 26:4773-4789

Feng J, Li JP, Zheng F, Xie F, Sun C (2016) Contrasting impacts of developing phases of two types of El Niño on southern China rainfall. J. Meteor. Soc. Japan, 94, $359-370$

Feng J, Wang L, Chen W, Fong SK, Leong KC (2010) Different impacts of two types of Pacific Ocean warming on Southeast Asia rainfall during boreal winter. J Geophys Res 115:D24122. doi:10.1029/2010JC014761

Fraedrich K (1994) ENSO impact on Europe?-A review. Tellus Ser A 46:541-552

Fraedrich K, Muller K (1992) Climate anomalies in Europe associated with ENSO extremes. Int J Climatol 12:25-31

Garfinkel CI, Hartmann DL (2010) Influence of the quasi-biennial oscillation on the North Pacific and El Niño teleconnections. J Geophys Res 115:D20116. doi:10.1029/2010JD014181

Graf HF, Zanchettin D (2012) Central Pacific El Niño, the "subtropical bridge”, and Eurasian climate. J Geophys Res 117:D01102

Gouirand I, Moron V (2003) Variability of the impact of El Niño-Southern Oscillation on sea-level pressure anomalies over the North Atlantic in January to March (1874-1996). Int J Climatol 23:1549-1566

Halpert MS, Ropelewski CF (1992) Surface temperature patterns associated with the Southern Oscillation. J Clim 5:577-593 
Hoskins BJ, Karoly DJ (1981) The steady linear response of a spherical atmosphere to thermal and orographic forcing. J Atmos Sci 38:1179-1196

Huang RH, Wu YF (1989) The influence of ENSO on the summer climate change in China and its mechanism. Adv Atmos Sci 6:21-32

Hurrell JW (1995) Decadal Trends in the North Atlantic Oscillation: Regional Temperatures and Precipitation. Science 269:676-679

Ineson S, Scaife AA (2009), The role of the stratosphere in the European climate response to El Niño. Nature Geoscience 2:32-36

Jin FF (1997) An equatorial ocean recharge paradigm for ENSO. Part I: Conceptual model. J Atmos Sci 54:811-829

Jin FF, An SI, Timmermann A, Zhao J (2003) Strong El Niño events and nonlinear dynamical heating. Geophys Res Lett 30:1120. doi: 10.1029/2002GL016356

Jones PD, Osborn TJ, Briffa KR (2003) Pressure-based measurements of the North Atlantic Oscillation (NAO): A comparison and an assessment of changes in the strength of the NAO and in its influence on surface climate parameters. AGU Geophys Monogr 34:51-62

Kalnay E, Coauthors (1996) The NCEP/NCAR 40-Year Reanalysis Project. Bull Amer Meteor Soc 77:437-471

Kao HY, Yu JY (2009) Contrasting eastern-Pacific and central-Pacific types of ENSO. J Clim 22:615-632

Klein SA, Soden BJ, Lau NC (1999) Remote sea surface temperature variations during ENSO: Evidence for a tropical atmospheric bridge. J Clim 12:917-932

Kug JS, Jin FF, An SI (2009) Two types of El Niño events: Cold tongue El Niño and warm pool ElNiño. J Clim 22:1499-1515

Kumar A, Hoerling MP (1998) Annual cycle of Pacific/North American seasonal predictability associated with different phases of ENSO. J Clim 11:3295-3308

Larkin NK, Harrison DE (2005) On the definition of El Niño and associated seasonal average U.S. weather anomalies. Geophys Res Lett 32:L13705. doi:10.1029/2005GL022738

Lee SK, Wang C, Enfield DB (2010) On the impact of central Pacific warming event 
on Atlantic tropical storm activity. Geophys. Res. Lett., 37, L17702, doi:10.1029/2010GL044459.

Li J, Wang J (2003) A new North Atlantic Oscillation index and its variability. Adv Atmos Sci 20:661-676

Li Y, and Lau NC (2012a) Impact of ENSO in the atmospheric variability over the North Atlantic in late winter-role of transient eddies. J Clim 25:320-342

Li Y, and Lau NC (2012b) Contributions of downstream eddy development to the teleconnection between ENSO and the atmospheric circulation over the North Atlantic. J Clim 25:4993-5010

Lim EP, Hendon HH, Rashid H (2013) Seasonal predictability of the southern annular mode due to its association with ENSO. J Clim 26:8037-8054

Mathieu PP, Sutton RT, Dong BW, Collins M (2004) Predictability of winter climate over the North Atlantic European region during ENSO events. J Clim $17: 1953-1974$

Merkel U, Latif M (2002) A high resolution AGCM study of the El Niño impact on the North Atlantic/European sector. Geophys Res Lett 29:1291. doi:10.1029/2001GL013726

Moron M, Gouirand I (2003) Seasonal modulation of the ENSO relationship with sea level pressure anomalies over the North Atlantic in October-March 1873-1996. Int J Climatol 23:143-155

Neelin JD, Battisti DS, Hirst AC, Jin FF, Wakata Y, Yamagata T, Zebiak SE (1998) ENSO theory. J Geophys Res 103:14 261-14 290

Parks TW, Burrus CS (1987) Design of linear-phase finite impulse-response. Digital Filter Design, T. W. Parks and C. S. Burrus, Eds., John Wiley \& Sons, 33-110

Pozo-Vázquez D, Gamiz-Fortis SR, Tovar-Pescador J, Esteban-Parra MJ, Castro-Diez Y (2005) ENSO events and associated European winter precipitation anomalies. Int J Climatol 25:17-31

Quadrelli R, Pavan V, Molteni F (2001) Wintertime variability of Mediterranean precipitation and its links with large-scale circulation anomalies. Clim Dyn $17: 457-466$ 
Rayner N A, Parker DE, Horton EB, Folland CK, Alexander LV, Rowell DP, Kent EC, Kaplan A (2003) Global analyses of sea surface temperature, sea ice, and night marine air temperature since the late nineteenth century. J Geophys Res 108:4407. doi:10.1029/2002JD002670

Ren HL, Jin FF (2011) Niño indices for two types of ENSO. Geophys Res Lett 38:L04704. doi:10.1029/2010GL046031

Ren HL, Jin FF, Stuecker M, Xie RH (2013), ENSO regime change since the late 1970s as manifested by two types of ENSO. J Meteor Soc Japan 91:835-842

Robertson AW, Mechoso CR, Kim YJ (2000) The influence of the Atlantic sea surface temperature anomalies on the North Atlantic Oscillation. J Clim 13:122-138

Robock A (2000) Volcanic eruptions and climate. Rev Geophys 38:191-219

Rogers JC (1984) The association between the North Atlantic Oscillation and the Southern Oscillation in the Northern Hemisphere. Mon Weather Rev 122:1999-2015

Ropelewski CF, Halpert MS (1987) Global and regional scale precipitation patterns associated with the El Niño/Southern Oscillation. Mon Wea Rev 115:1606-1626

Ropelewski CF, Halpert MS (1996) Quantifying Southern Oscillation-precipitation relationships. J Clim 9:1043-1059

Schopf PS, Suarez MJ (1988) Vacillations in a coupled ocean-atmosphere model. J Atmos Sci 45:549-566

Stuecker M, Jin FF, Timmermann A, McGregor S (2015) Combination Mode Dynamics of the anomalous North-West Pacific Anticyclone. J Clim 28:1093-1111

The GFDL Global Atmospheric Model Development Team (2004) The New GFDL Global Atmosphere and Land Model AM2-LM2: Evaluation with Prescribed SST Simulations. J Clim 17:4641-4673

Toniazzo T, Scaife AA (2006) The influence of ENSO on winter North Atlantic climate. Geophys Res Lett 33:L24704. doi:10.1029/2006GL027881

Trenberth KE, Caron JM (2000) The Southern Oscillation revisited: Sea level pressure, surface temperatures, and precipitation. J Clim 13:4358-4365 
van Loon H, Madden RA (1981) The Southern Oscillation. Part I: Global associations with pressure and temperature in northern winter. Mon Wea Rev 109:1150-1162

Wallace JM, Gutzler DS (1981) Teleconnections in the geopotential field during the Northern Hemisphere winter. Mon Wea Rev 109:784-812

Wallace JM, Rasmusson EM, Mitchell TP, Kousky VE, Sarachik ES, Von Storch H (1998) On the structure and evolution of ENSO-related climate variability in the tropical Pacific: Lessons from TOGA. J Geophys Res 103:14 241-14 259

Wang B, Wu R, Fu X (2000) Pacific-East Asian teleconnection: How does ENSO affect East Asian Climate? J Clim 13:1517-1536

Wang C (2002) Atlantic climate variability and its associated atmospheric circulation cells. J Clim 15:1516-1536

Watanabe M, Kimoto M (1999) Tropical-extratropical connection in the Atlantic atmosphere-ocean variability. Geophys Res Lett 26:2247-2250

Weng H, Ashok K, Behera SK, Rao SA, Yamagata T (2007) Impacts of recent El Niño Modoki on dry/wet conditions in the Pacific rim during boreal summer. Clim Dyn 29:113-129

Wilson AB, Bromwich DH, Hines KM (2016) Simulating the mutual forcing of anomalous high-southern latitude atmospheric circulation by El Niño flavors and the Southern Annular Mode. J Clim 29:2291-2309

Wilson AB, Bromwich DH, Hines KM, Wang SH (2014) El Niño flavors and their simulated impacts on atmospheric circulation in the high southern latitudes. J Clim 27:8934-8955

Wolter K (1987) The Southern Oscillation in surface circulation and climate over the tropical Atlantic, eastern Pacific, and Indian Oceans as captured by cluster analysis. J Clim Appl Meteorol 26:540-558

Wu A, Hsieh WW (2004) The nonlinear association between ENSO and the Euro-Atlantic winter sea level pressure. Clim Dyn 23:859-868

Wu Z, Zhang P (2015) Interdecadal variability of the mega-ENSO-NAO synchronization in winter. Clim Dyn 45:1117-1128

Wyrtki K (1975) El Niño-The dynamic response of the equatorial Pacific Ocean to 
atmospheric forcing. J Phys Oceanogr 5:572-584

Xiao D, Li JP (2011) Mechanism of stratospheric decadal abrupt cooling in the early 1990s as influenced by the Pinatubo eruption. Chinese Sci Bull 56:772-780

Xie F, Li JP, Tian WS, Feng J, Huo Y (2012) Signals of El Niño Modoki in the tropical tropopause layer and stratosphere. Atmos Chem Phys 12:5295-5237

Xie SP, Hu K, Hafner J, Tokinaga H, Du Y, Huang G, Sampe T (2009) Indian Ocean capacitor effect on Indo-Western Pacific climate during the summer following El Niño. J Climate 22:730-747

Xie SP, Kosaka Y, Du Y, Hu K, Chowdary JS, Huang G (2016) Indo-Western Pacific Ocean capacitor and coherent climate anomalies in post-ENSO summer: A review. Adv Atmos Sci 33:411-432

Yang J, Liu Q, Xie SP, Liu Z, Wu L (2007) Impact of the Indian Ocean SST basin mode on the Asian summer monsoon. Geophys Res Lett 34:L02708. doi:10.1029/2006GL028571

Yu JY, Zou Y, Kim ST, Lee T(2012) The changing impact of El Niño on US winter temperature. Geophys. Res. Lett., 39, L15702, doi:10.1029/2012GL052483.

Zhang R, Sumi A, Kimoto M (1996) Impacts of El Niño on the East Asian monsoon: A diagnostic study of the '86/87 and '91/92 events. J Meteor Soc Japan, 74:49-62

Zhang W, Li H, Stuecker M, Jin FF, Turner AG (2016) A new understanding of El Nino's impact over East Asia: Dominance of the ENSO combination mode. J Clim 29:4347-4359

Zhang W. Wang L, Xiang B, Qi L, He J (2015) Impacts of two types of La Nina on the NAO during boreal winter. Clim Dyn 44:1351-1366

Zhang W, Jin FF, Turner A (2014) Increasing autumn drought over southern China associated with ENSO regime shift. Geophys Res Lett 41. doi:10.1002/2014GL060130.

Zhang W, Jin FF, Li JP, Ren HL (2011) Contrasting impacts of two-type El Niño over the western North Pacific. J Meteor Soc Japan 89:563-569

Zhang W, Jin FF, Zhao JX, Qi L, Ren HL (2013) The possible influence of a non-conventional El Niño on the severe autumn drought of 2009 in Southwest 
China. J Clim 26:8392-8405

789 


\section{Figure Captions}

Figure 1. (a) Time series of normalized DJF-Niño3.4 (red) and JFM-NAO (blue) indices. (b) Sliding correlation between DJF-Niño3.4 and JFM-NAO indices on with moving windows of 11 (blue) and 21 (red) years. Blue and red dashed horizontal lines in (b) indicate correlation coefficients exceeding the statistical $90 \%$ confidence level for the 11- and 21- year windows, respectively.

Figure 2. Scatterplot of the JFM-NAO index as a function of the normalized DJF-Niño3.4 index for EP El Niño (red dot), CP El Niño (orange dot), EP La Niña (blue dot), and CP La Niña (green dot) events. Stars denote composites of the different type of events, which exceed the statistical 95\% confidence level.

Figure 3. Composite SST (contour in ${ }^{\circ} \mathrm{C}$ ) and near-surface wind (vector in $\mathrm{m} / \mathrm{s}$ ) anomalies during La Niña winters associated with (a) positive NAO phase and (b) negative NAO phase. Light (dark) shading indicates areas for which the SST anomaly composites exceed the $90 \%$ (95\%) confidence level. The near-surface wind anomalies are shown only when the anomalous wind speed is above $0.5 \mathrm{~m} / \mathrm{s}$.

Figure 4. Composite SST (contour in ${ }^{\circ} \mathrm{C}$ ) and near-surface wind (vector in $\mathrm{m} / \mathrm{s}$ ) anomalies for (a) EP El Niño, (b) CP El Niño, (c) EP La Niña, and (d) CP La Niña. Light (dark) shading indicates the values exceeding the $90 \%$ (95\%) confidence level. The near-surface wind anomalies below the $80 \%$ confidence level are omitted.

Figure 5. Composite SLP anomalies (hPa) for (a) EP El Niño, (b) CP El Niño, (c) EP La Niña, and (d) CP La Niña. Horizontal and diagonal lines, and cross-hatched regions indicate where the composites exceed the $80 \%, 90 \%$, and $95 \%$ confidence level, respectively.

Figure 6. Meridional-vertical geopotential height anomalies (m) zonally averaged over $10^{\circ}-80^{\circ} \mathrm{W}$ in the North Atlantic for (a) EP El Niño, (b) CP El Niño, (c) EP La Niña, and (d) CP La Niña. Shading indicates values exceeding the $80 \%$ and $90 \%$ confidence level respectively.

Figure 7. Composite zonal wind anomalies (m/s) at $300 \mathrm{hPa}$ for (a) EP El Niño, (b) CP El Niño, (c) EP La Niña, and (d) CP La Niña. Light (dark) red and blue 
shadings indicate positive and negative anomalies exceeding the $80 \%(90 \%)$ confidence level, respectively.

Figure 8. Composite surface air temperature $\left({ }^{\circ} \mathrm{C}\right.$ ) for (a) EP El Niño, (b) CP El Niño, (c) EP La Niña, and (d) CP La Niña. Horizontal and diagonal lines, and cross-hatched regions indicate where the composites exceed the $80 \%, 90 \%$, and 95\% confidence level, respectively.

Figure 9. Ensemble mean JFM SLP response (hPa) to tropical Pacific SST anomaly forcing of (a) EP El Niño, (b) CP El Niño, (c) EP La Niña, and (d) CP La Niña. The values of the anomalous NAO indices are given as inserts.

Figure 10. Ensemble mean JFM zonal wind anomalies (m/s) at $300 \mathrm{hPa}$ in response to tropical Pacific SST anomaly forcing of (a) EP El Niño, (b) CP El Niña, (c) EP La Niña, and (d) CP La Niña.

Figure 11. Horizontal distributions of SST (shading in ${ }^{\circ} \mathrm{C}$ ) and SLP (contours in hPa) anomaly for (a) EP El Niño minus EP La Niña, (b) CP El Niño minus CP La Niña, (c) EP El Niño plus EP La Niña and (d) CP El Niño plus CP La Niña. Only SST values exceeding the $95 \%$ confidence level are displayed in shading.

Figure 12. Same as Figure 12, except that the SLP anomalies (hPa) are the ensemble mean from the model experiments.

Figure 13. Precipitation anomalies $(\mathrm{mm} / \mathrm{d})$ over the eastern equatorial Pacific $\left(155^{\circ}-90^{\circ} \mathrm{W}, 5^{\circ} \mathrm{S}-5^{\circ} \mathrm{N}\right)$ for EP El Niño minus EP La Niña (EPW-EPC), EP El Niño plus EP La Niña (EPW+EPC), CP El Niño minus CP La Niña (CPW-CPC), and CP El Niño plus CP La Niña (CPW+CPC).

Figure 14. Partial correlation coefficient between the SLP and SST anomalies over the tropical North Atlantic $\left(0^{\circ}-30^{\circ} \mathrm{N}, 20^{\circ}-80^{\circ} \mathrm{W}\right)$ after removing the linear Nino3.4 index. The hatching indicates the values exceeding the 95\% confidence level.

Figure 15. Time-height diagram of zonal wind anomalies $(\mathrm{m} / \mathrm{s})$ in NCEP reanalysis averaged over $10^{\circ}-80^{\circ} \mathrm{W}$ at $60^{\circ} \mathrm{N}$ for (a) EP El Niño, (b) CP El Niño, (c) EP La Niña and (d) CP La Niña. Shading indicates values exceeding the $90 \%$ and $95 \%$ confidence level respectively. 
851 events).

\begin{tabular}{|c|l|l|}
\hline & \multicolumn{1}{|c|}{ El Niño } & \multicolumn{1}{|c|}{ La Niña } \\
\hline EP type & $1951 / 52,1952 / 53,1963 / 64$, & $1954 / 55,1955 / 56,1964 / 65$, \\
$(8,8)$ & $1965 / 66,1969 / 70,1972 / 73$, & $1967 / 68,1971 / 72,1984 / 85$, \\
& $1976 / 77,1997 / 98$ & $1995 / 96,2005 / 06$ \\
\hline CP type & $1953 / 54,1957 / 58,1968 / 69$, & $1973 / 74,1974 / 75,1975 / 76$, \\
$(9,8)$ & $1977 / 78,1979 / 80,1986 / 87$, & $1988 / 89,1998 / 99,2000 / 01$, \\
& $2002 / 03,2004 / 05,2009 / 10$ & $2010 / 11,2011 / 12$ \\
\hline
\end{tabular}

852

Table 2. List of the conducted SST perturbation experiments.

\begin{tabular}{|c|l|}
\hline Experiment & \multicolumn{1}{c|}{ Description of the SST perturbation } \\
\hline EPW & $\begin{array}{l}\text { Positive anomalies associated with EP El Niño winters are } \\
\text { imposed in the tropical Pacific }\left(30^{\circ} \mathrm{S}-30^{\circ} \mathrm{N}, 120^{\circ} \mathrm{E}-90^{\circ} \mathrm{W}\right)\end{array}$ \\
\hline $\mathrm{CPW}$ & As in EPW but for the CP El Niño winters \\
\hline EPC & $\begin{array}{l}\text { Negative anomalies associated with EP La Niña winters are } \\
\text { imposed in the tropical Pacific }\left(30^{\circ} \mathrm{S}-30^{\circ} \mathrm{N}, 120^{\circ} \mathrm{E}-90^{\circ} \mathrm{W}\right) .\end{array}$ \\
\hline $\mathrm{CPC}$ & As in EPC but for the CP La Niña winters \\
\hline
\end{tabular}

855 Table 3. Linear correlation coefficients (R) between DJF-Niño3.4 and JFM-NAO 856 indices (with sample size n) for different episodes. Asterisks indicate correlation 857 coefficients exceeding the $95 \%$ confidence level.

\begin{tabular}{|c|l|l|l|l|l|}
\hline & $\begin{array}{l}\text { All } \\
\text { years }\end{array}$ & $\begin{array}{l}\text { All years } \\
\text { except } \\
\text { volcano years }\end{array}$ & $\begin{array}{l}\text { All years } \\
\text { except volcano } \\
\text { and EP La } \\
\text { Niña years }\end{array}$ & $\begin{array}{l}\text { El Niño } \\
\text { and CP La } \\
\text { Niña } \\
\text { years }\end{array}$ & $\begin{array}{l}\text { All years } \\
\text { except } \\
\text { volcano and } \\
\text { ENSO years }\end{array}$ \\
\hline $\mathrm{n}$ & 61 & 55 & 47 & 25 & 22 \\
\hline $\mathrm{R}$ & -0.23 & $-0.33^{*}$ & $-0.50^{*}$ & $-0.63^{*}$ & -0.04 \\
\hline
\end{tabular}


(a) Nino3.4 and NAO Time Series

861

862

863

864

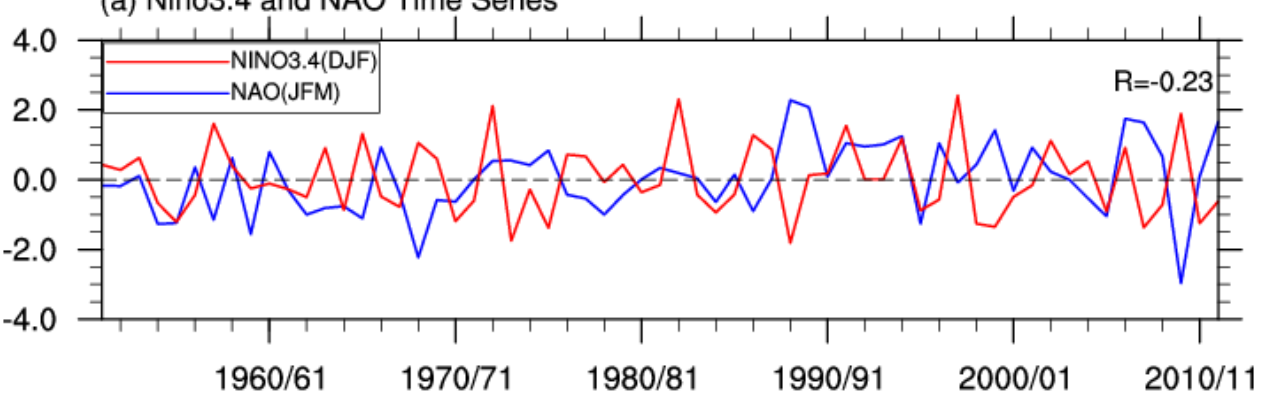

(b) Sliding Correlation between Nino3.4 and NAO

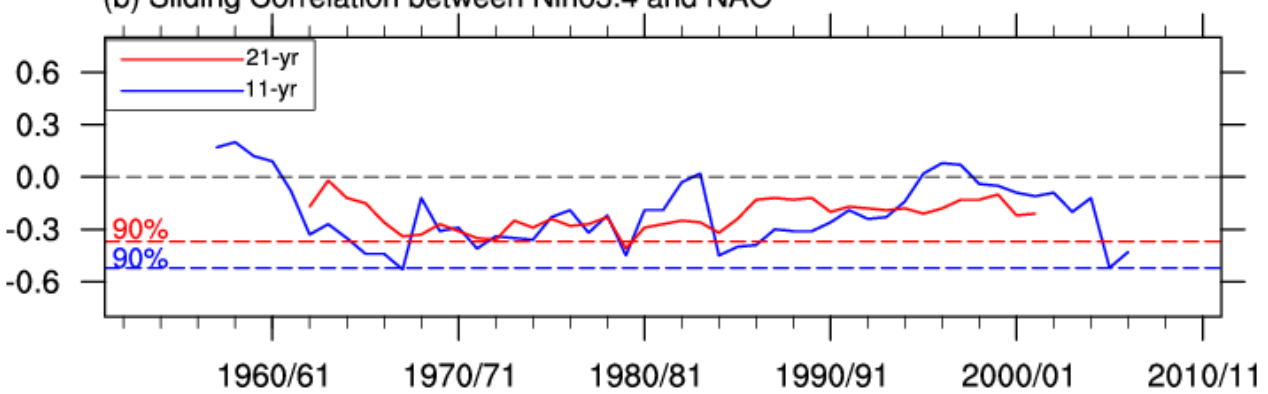

869 Figure 1. (a) Time series of normalized DJF-Niño3.4 (red) and JFM-NAO (blue)

870 indices. (b) Sliding correlation between DJF-Niño3.4 and JFM-NAO indices on with

871 moving windows of 11 (blue) and 21 (red) years. Blue and red dashed horizontal lines

872 in (b) indicate correlation coefficients exceeding the statistical $90 \%$ confidence level

873 for the 11- and 21- year windows, respectively. 
Normalized Index

879

880

881

882

883

884

885

886

887

888

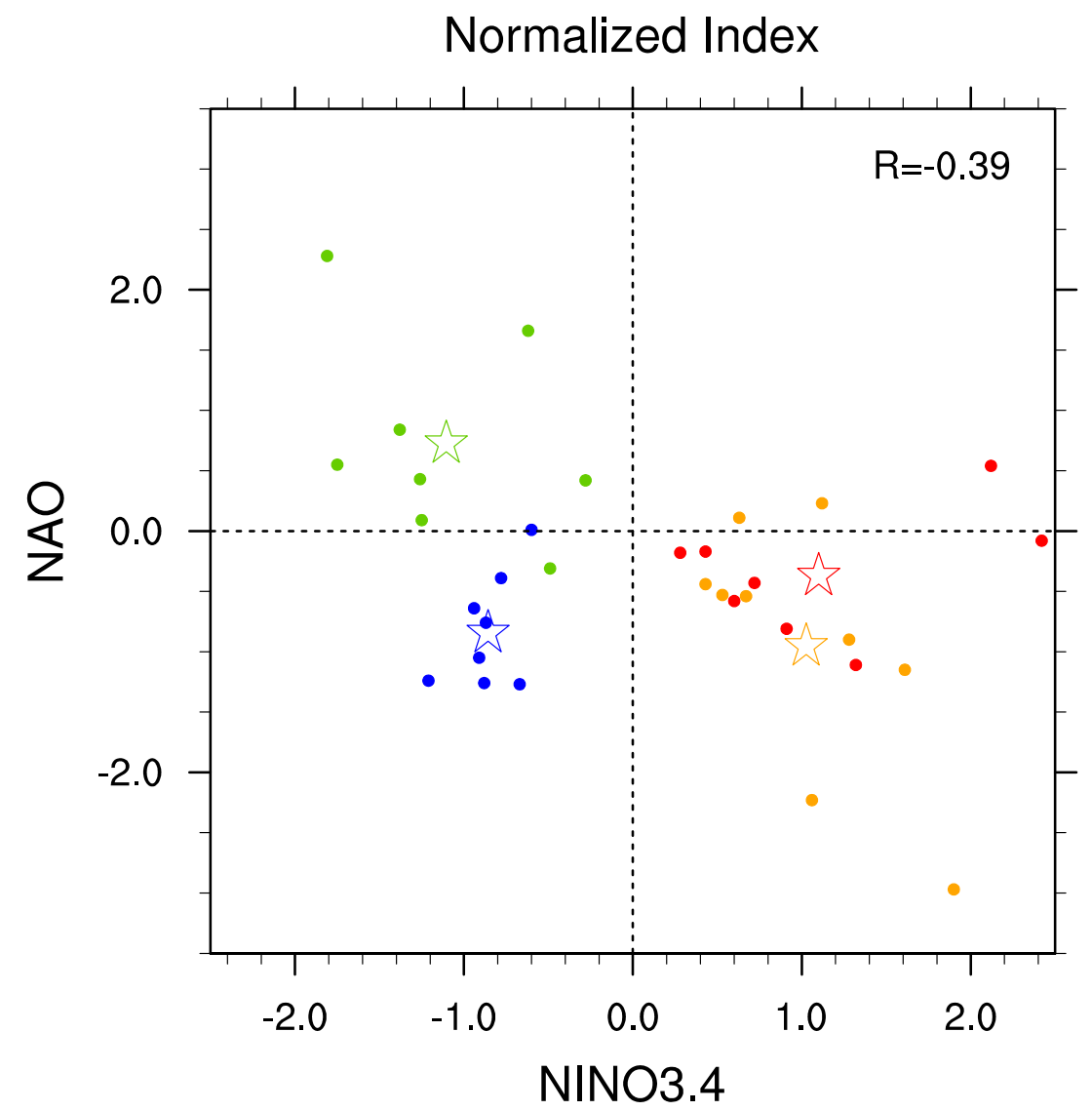

889 Figure 2. Scatterplot of the JFM-NAO index as a function of the normalized 890 DJF-Niño3.4 index for EP El Niño (red dot), CP El Niño (orange dot), EP La Niña

891 (blue dot), and CP La Niña (green dot) events. Stars denote composites of the 892 different type of events, which exceed the statistical 95\% confidence level.

893

894

895

896

897 


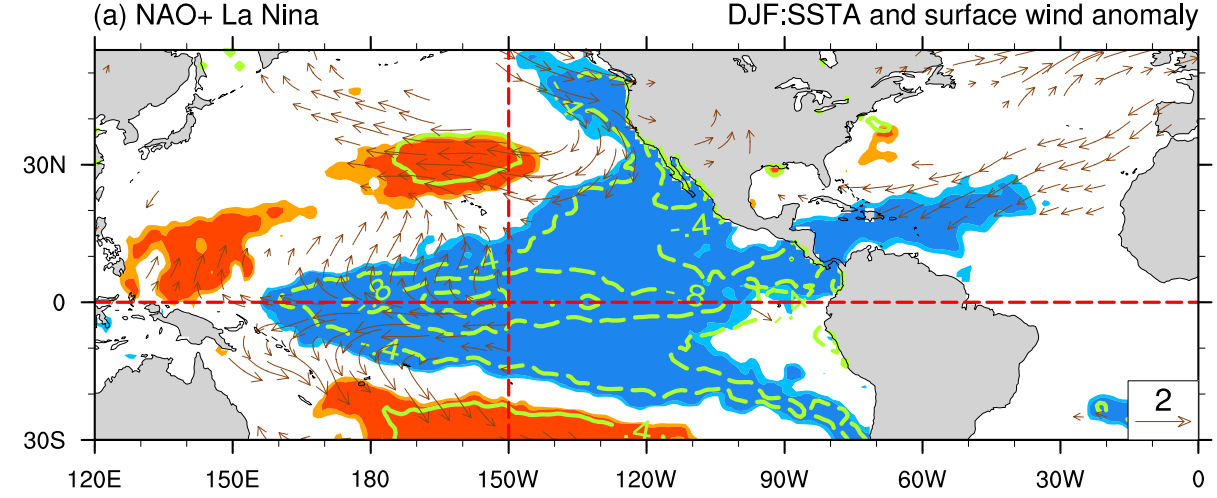

(b) NAO- La Nina DJF:SSTA and surface wind anomaly

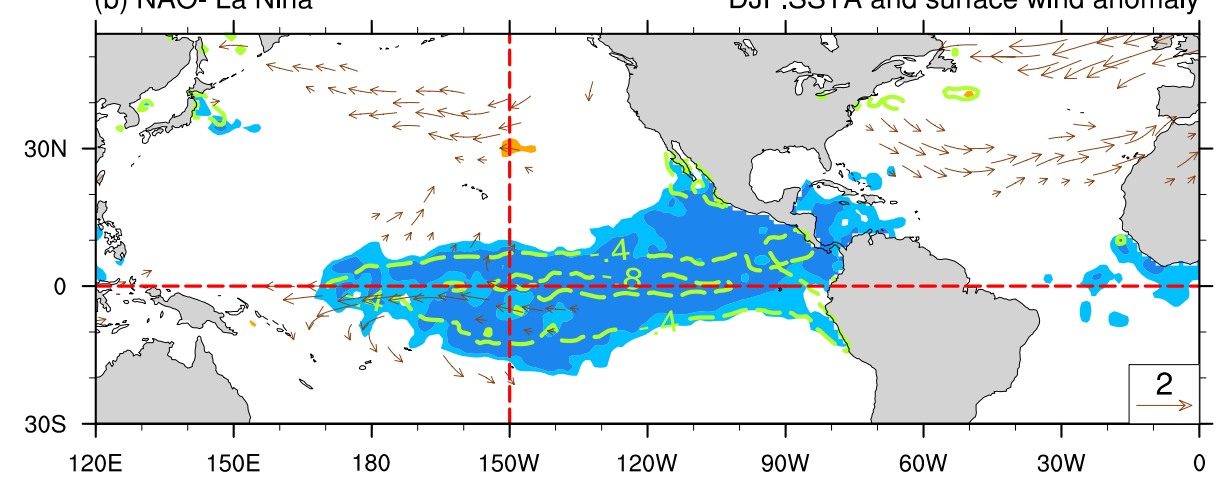

910

911 Figure 3. Composite SST and near-surface wind anomalies $\left({ }^{\circ} \mathrm{C}\right)$ during La Niña

912 winters associated with (a) positive NAO phase and (b) negative NAO phase. Light

913 (dark) shading indicates areas for which the SST anomaly composites exceed the 90\%

914 (95\%) confidence level. The near-surface wind anomalies are shown only when the

915 anomalous wind speed is above $0.5 \mathrm{~m} / \mathrm{s}$.

916 

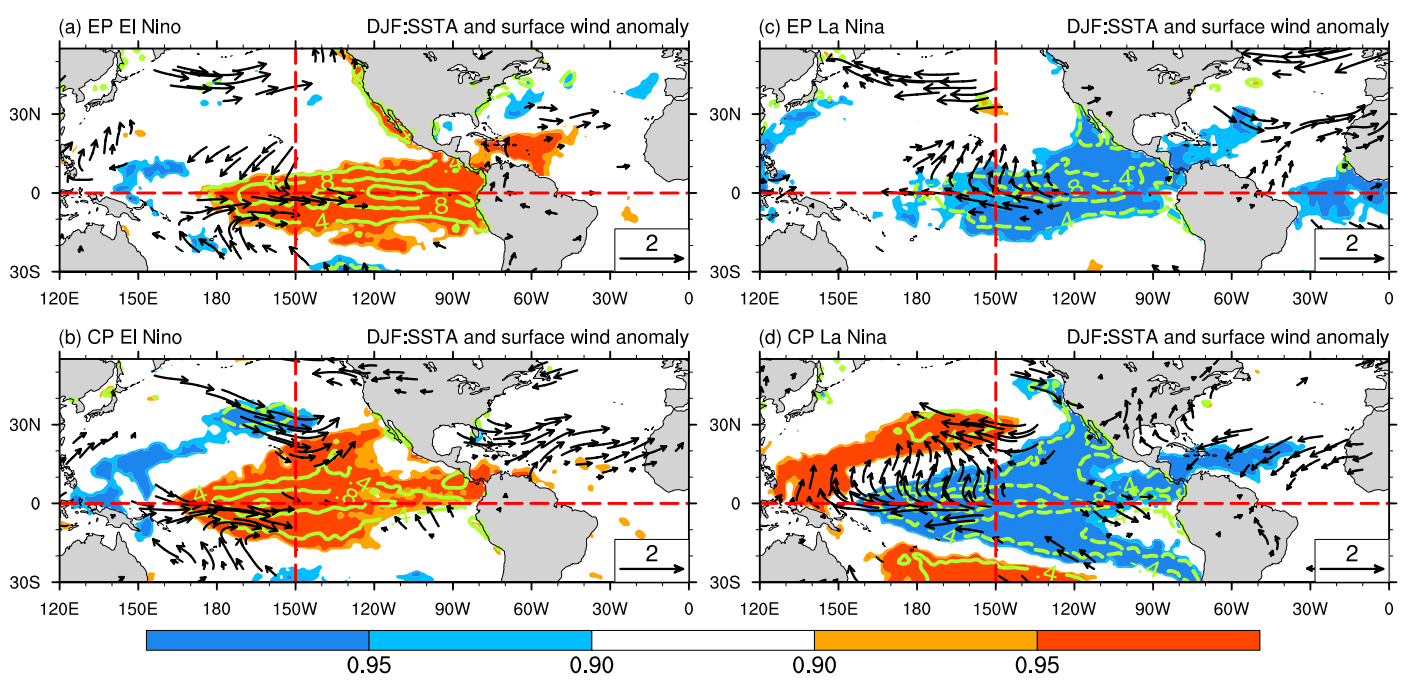

923

924

925

926

Figure 4. Composite SST (contour in ${ }^{\circ} \mathrm{C}$ ) and near-surface wind (vector in $\mathrm{m} / \mathrm{s}$ )

927 anomalies for (a) EP El Niño, (b) CP El Niño, (c) EP La Niña, and (d) CP La Niña.

928 Light (dark) shading indicates the values exceeding the 90\% (95\%) confidence level.

929 The near-surface wind anomalies below the $80 \%$ confidence level are omitted. 

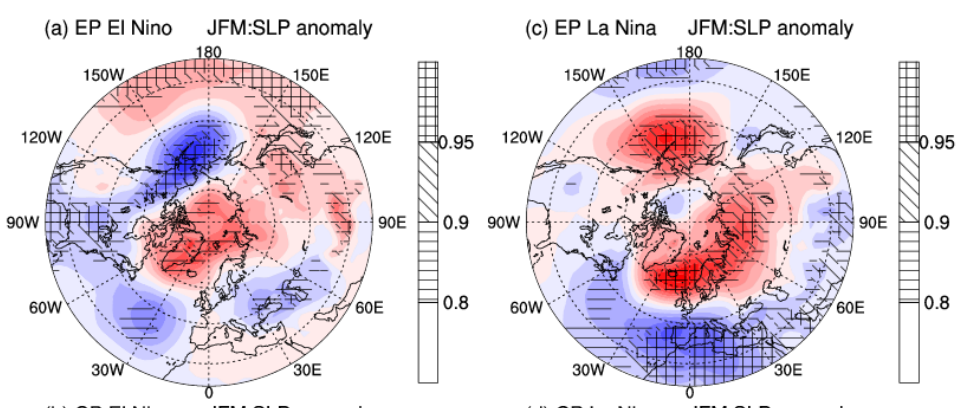

936

937

(b) CP EI Nino JFM:SLP anomaly (d) CP La Nina JFM:SLP anomaly
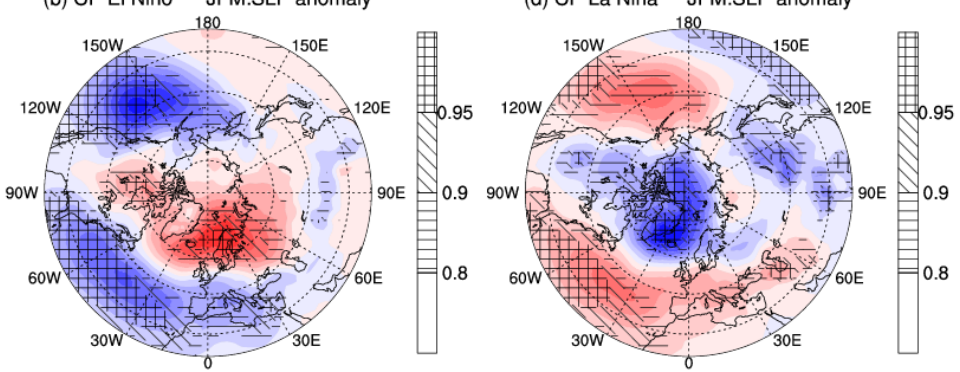

939

940

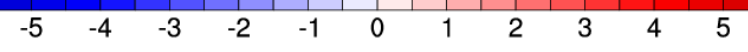

941 Figure 5. Composite SLP anomalies (hPa) for (a) EP El Niño, (b) CP El Niño, (c) EP

942 La Niña, and (d) CP La Niña. Horizontal and diagonal lines, and cross-hatched

943 regions indicate where the composites exceed the $80 \%, 90 \%$, and $95 \%$ confidence

944 level, respectively.

945

946 
949

950

951

952

953
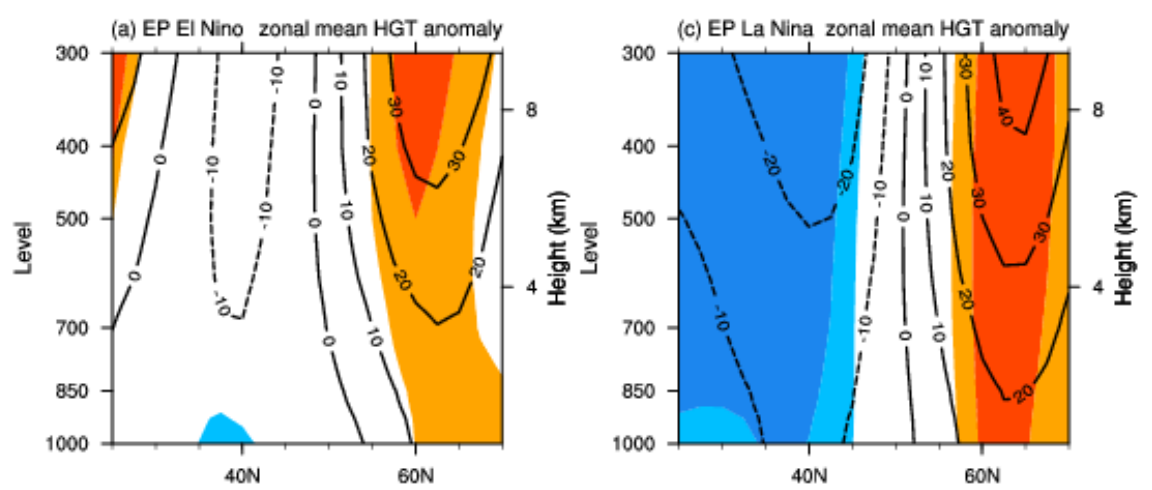

954

955

956

957

958
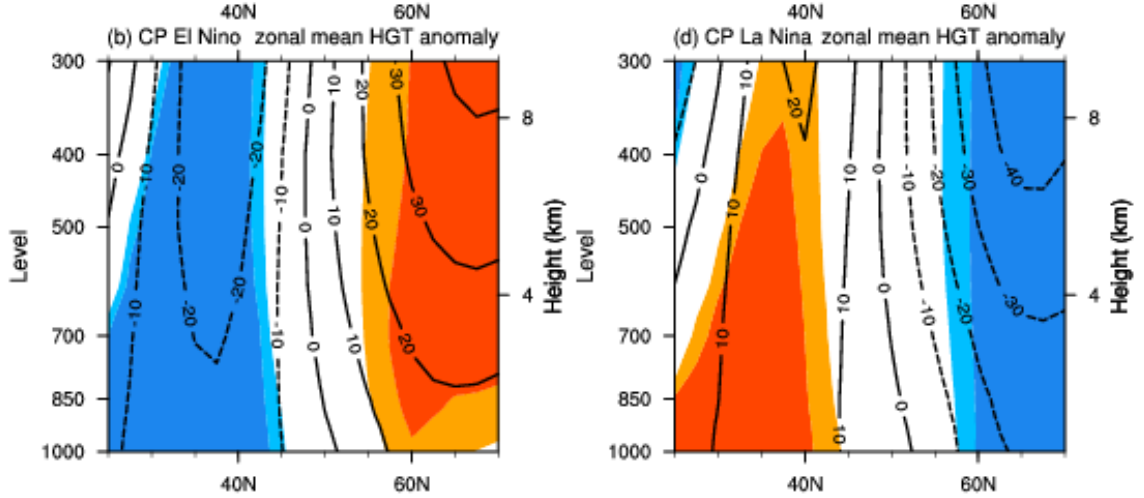

958

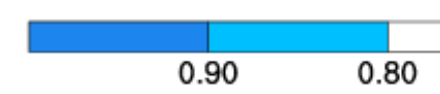

959

960

961 Figure 6. Meridional-vertical geopotential height anomalies (m) zonally averaged

962 over $10^{\circ}-80^{\circ} \mathrm{W}$ in the North Atlantic for (a) EP El Niño, (b) CP El Niño, (c) EP La

963 Niña, and (d) CP La Niña. Shading indicates values exceeding the $80 \%$ and $90 \%$

964 confidence level respectively.

965

966 

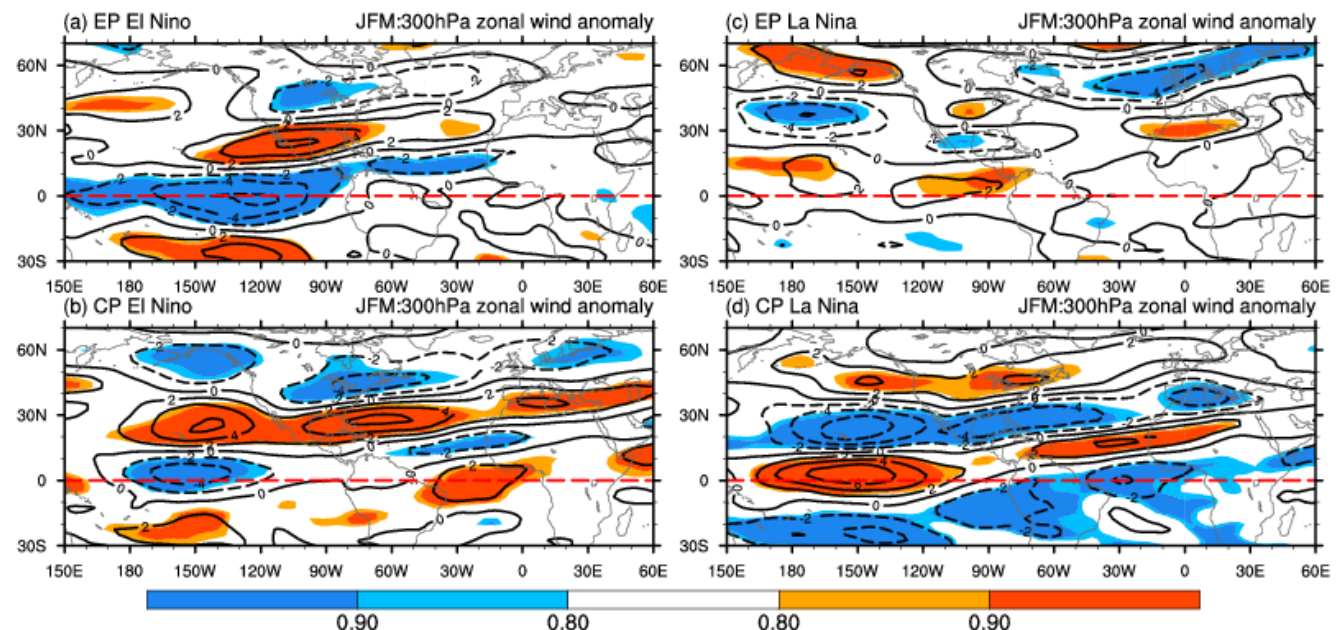

975

976 Figure 7. Composite zonal wind anomalies (m/s) at $300 \mathrm{hPa}$ for (a) EP El Niño, (b)

977 CP El Niño, (c) EP La Niña, and (d) CP La Niña. Light (dark) red and blue shadings

978 indicate positive and negative anomalies exceeding the $80 \%(90 \%)$ confidence level,

979 respectively.

980

981

982 

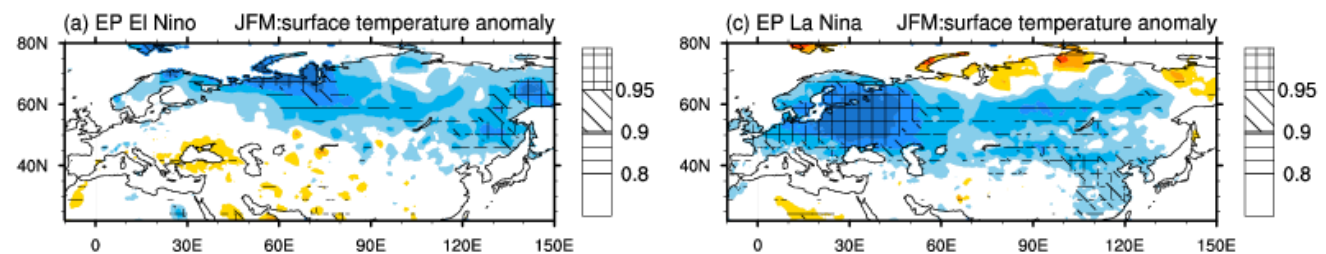

988

989

990

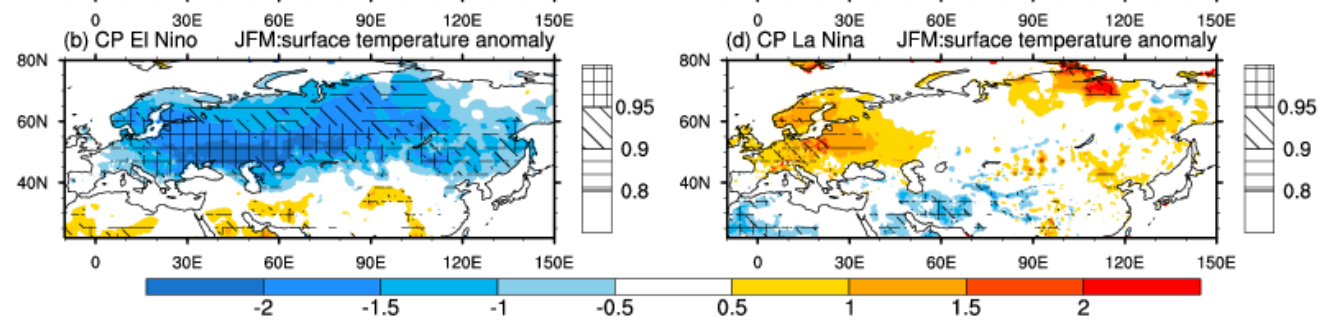

991

992 Figure 8. Composite surface air temperature $\left({ }^{\circ} \mathrm{C}\right)$ for (a) EP El Niño, (b) CP El Niño,

993 (c) EP La Niña, and (d) CP La Niña. Horizontal and diagonal lines, and cross-hatched

994 regions indicate where the composites exceed the $80 \%, 90 \%$, and $95 \%$ confidence

995 level, respectively. 
996

997

998

999

1000

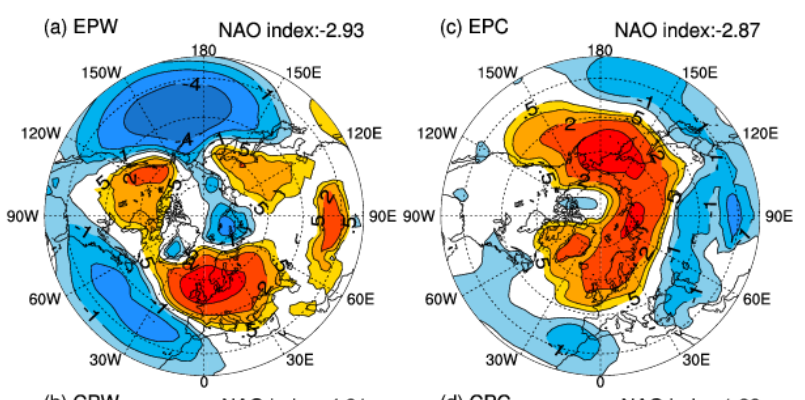

1001

1002

1003

1004

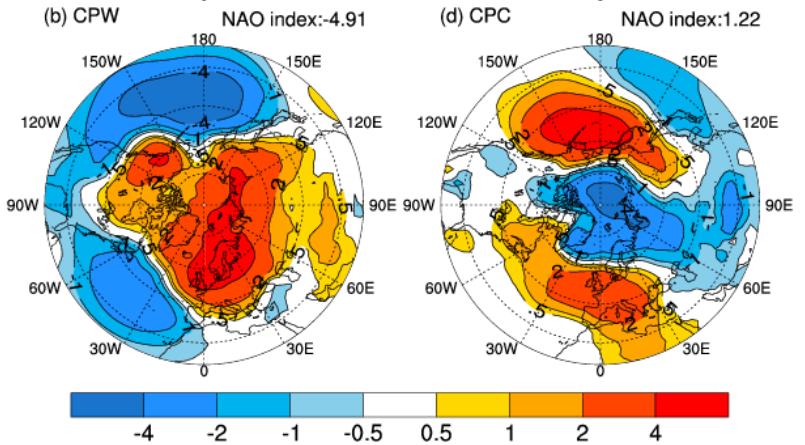

1005

1006 Figure 9. Ensemble mean JFM SLP response (hPa) to tropical Pacific SST anomaly

1007 forcing of (a) EP El Niño, (b) CP El Niño, (c) EP La Niña, and (d) CP La Niña. The 1008 values of the anomalous NAO indices are given as inserts. 
1010

1011

1012

1013
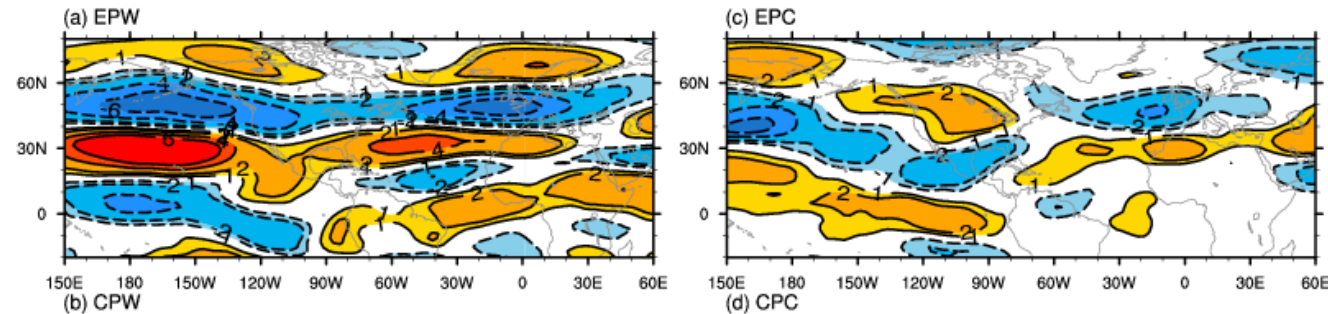

1014

1015

1016
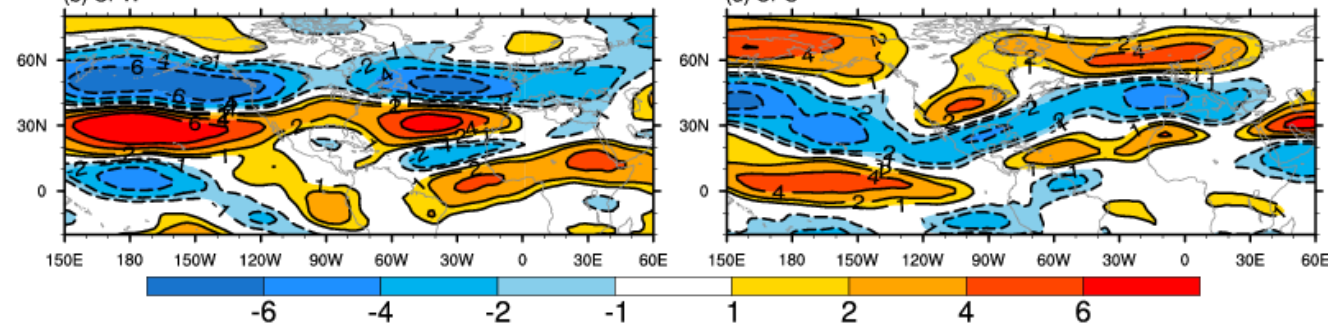

1017

1018 Figure 10. Ensemble mean JFM zonal wind anomalies $(\mathrm{m} / \mathrm{s})$ at $300 \mathrm{hPa}$ in response to

1019 tropical Pacific SST anomaly forcing of (a) EP El Niño, (b) CP El Niña, (c) EP La

1020 Niña, and (d) CP La Niña. 

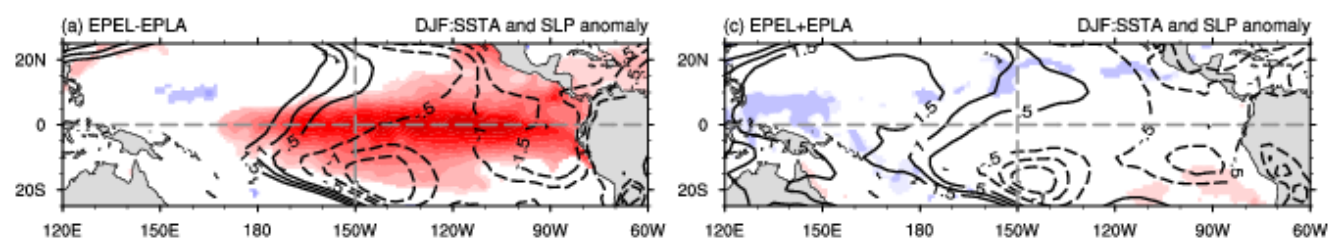

1026
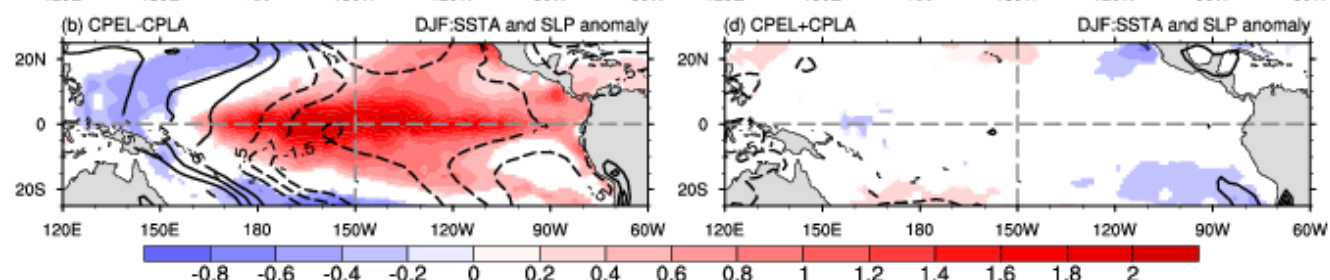

1030 Figure 11. Horizontal distributions of SST (shading in ${ }^{\circ} \mathrm{C}$ ) and SLP (contours in $\mathrm{hPa}$ ) anomaly for (a) EP El Niño minus EP La Niña, (b) CP El Niño minus CP La Niña, (c) EP El Niño plus EP La Niña and (d) CP El Niño plus CP La Niña. Only SST values exceeding the $95 \%$ confidence level are displayed in shading. 
1036

1037

1038
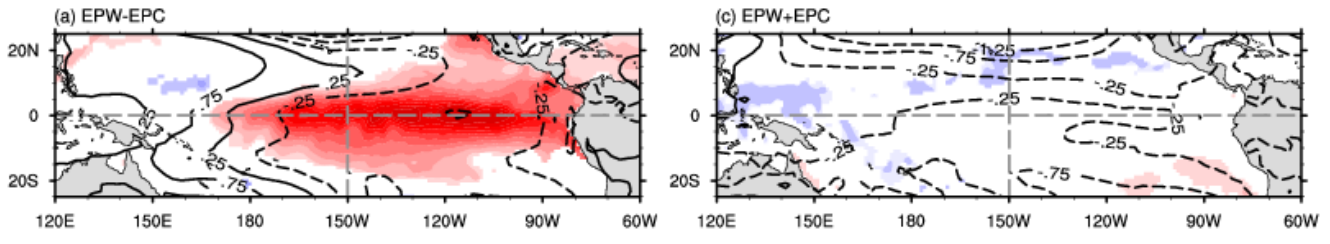

1039

1040

1041

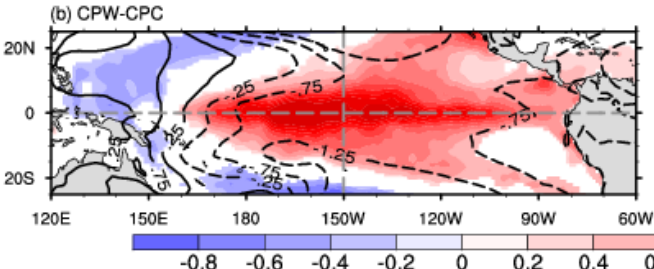

(d) $\mathrm{CPW}+\mathrm{CPC}$

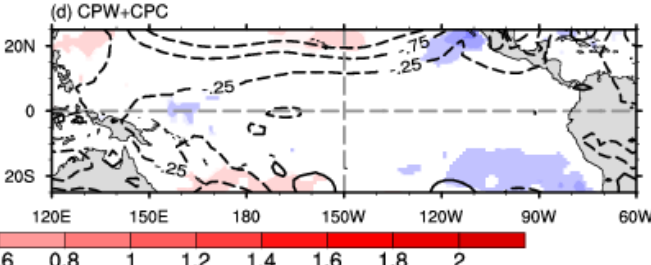

1042

1043 Figure 12. Same as Figure 12, except that the SLP anomalies (hPa) are the ensemble

1044 mean from the model experiments.

1045

1046 
1048

1049

1050

1051

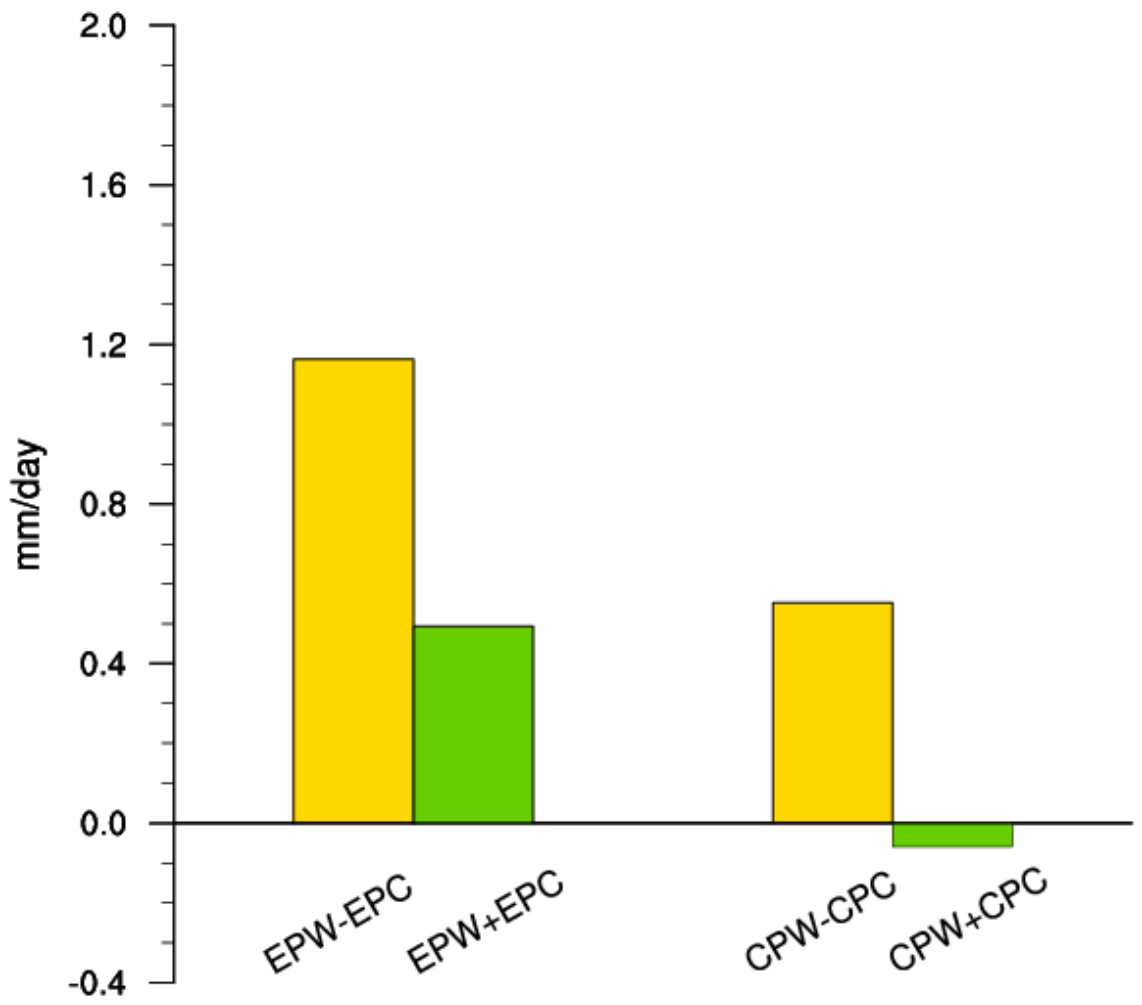

1057

1052

1053

1054

1055

1056

1058

1059

1060 Figure 13. Precipitation anomalies $(\mathrm{mm} / \mathrm{d})$ over the eastern equatorial Pacific

$1061\left(155^{\circ}-90^{\circ} \mathrm{W}, 5^{\circ} \mathrm{S}-5^{\circ} \mathrm{N}\right)$ for EP El Niño minus EP La Niña (EPW-EPC), EP El Niño

1062 plus EP La Niña (EPW+EPC), CP El Niño minus CP La Niña (CPW-CPC), and CP El

1063 Niño plus CP La Niña (CPW+CPC). 
1066

1067

1068

1069

1070

1071

1072

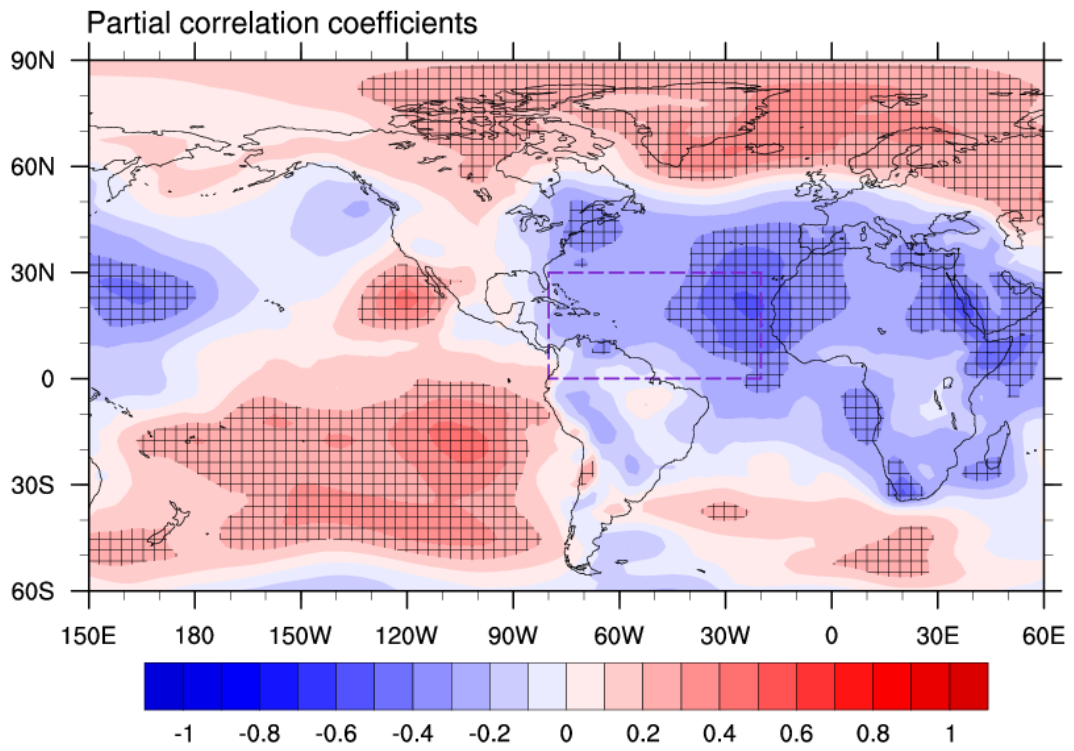

1074

1075 Figure 14. Partial correlation coefficient between the SLP and SST anomalies over the

1076 tropical North Atlantic $\left(0^{\circ}-30^{\circ} \mathrm{N}, 20^{\circ}-80^{\circ} \mathrm{W}\right)$ after removing the linear Nino3.4 index.

1077 The hatching indicates the values exceeding the $95 \%$ confidence level.

1078 
1080

1081

1082
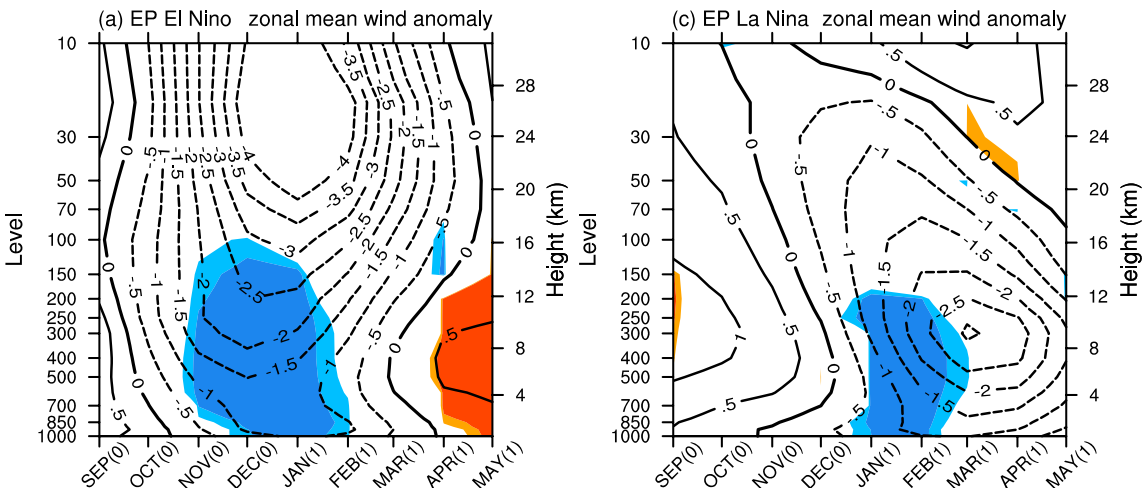

1085

1086
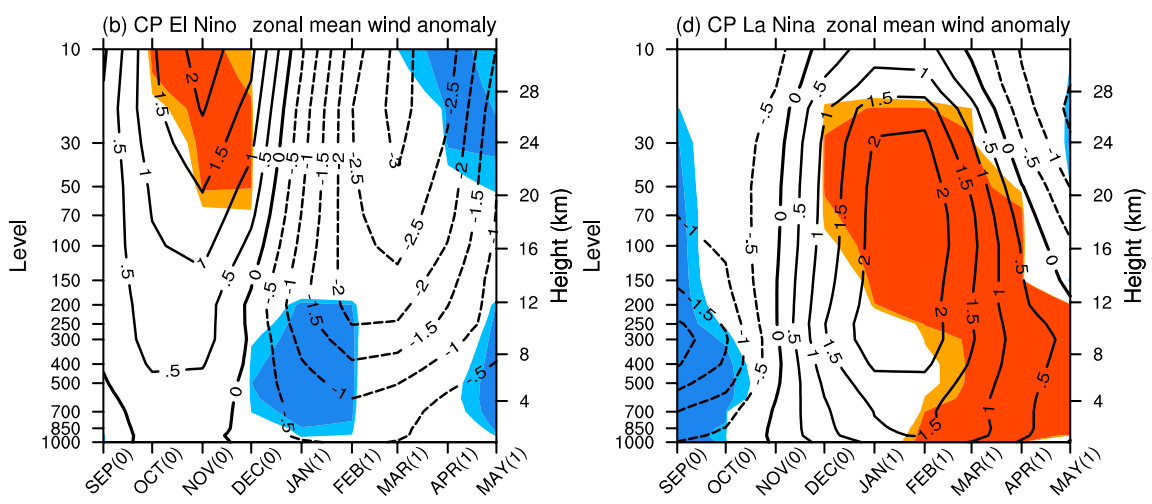

1090

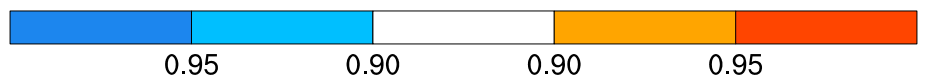

1091

1092 Figure 15. Time-height diagram of zonal wind anomalies $(\mathrm{m} / \mathrm{s})$ in NCEP reanalysis

1093 averaged over $10^{\circ}-80^{\circ} \mathrm{W}$ at $60^{\circ} \mathrm{N}$ for (a) EP El Niño, (b) CP El Niño, (c) EP La Niña

1094 and (d) CP La Niña. Shading indicates values exceeding the 90\% and 95\% confidence

1095 level respectively.

1096 